\title{
Dark aerobic sulfide oxidation by anoxygenic phototrophs in anoxic waters
}

\author{
Jasmine S. Berg (i,,$^{1,2^{\star}}$ Petra Pjevac, ${ }^{3}$ \\ Tobias Sommer, ${ }^{4}$ Caroline R.T. Buckner, ${ }^{1}$ \\ Miriam Philippi, ${ }^{1}$ Philipp F. Hach, ${ }^{1}$ Manuel Liebeke, ${ }^{1}$ \\ Moritz Holtappels, ${ }^{5}$ Francesco Danza, ${ }^{6,7}$ \\ Mauro Tonolla, ${ }^{6,7}$ Anupam Sengupta, ${ }^{8}$ \\ Carsten J. Schubert, ${ }^{4}$ Jana Milucka ${ }^{1}$ and \\ Marcel M.M. Kuypers ${ }^{1}$ \\ ${ }^{1}$ Department of Biogeochemistry, Max Planck Institute \\ for Marine Microbiology, 28359, Bremen, Germany. \\ ${ }^{2}$ Department of Environmental Systems Science, \\ Institute of Biogeochemistry and Pollutant Dynamics, \\ Swiss Federal Institute of Technology Zurich, 8092, \\ Zurich, Switzerland. \\ ${ }^{3}$ Division of Microbial Ecology, Department of \\ Microbiology and Ecosystem Science, University of \\ Vienna, 1090, Vienna, Austria. \\ ${ }^{4}$ Eawag, Swiss Federal Institute of Aquatic Science and \\ Technology, Kastanienbaum, Switzerland. \\ ${ }^{5}$ Alfred-Wegener-Institut, Helmholtz-Zentrum für Polar- \\ und Meeresforschung, Am Alten Hafen 26, 27568, \\ Bremerhaven, Germany. \\ ${ }^{6}$ Laboratory of Applied Microbiology (LMA), Department \\ for Environmental Constructions and Design (DACD), \\ University of Applied Sciences and Arts of Southern \\ Switzerland (SUPSI), via Mirasole 22a, 6500, Bellinzona, \\ Switzerland. \\ ${ }^{7}$ Microbiology Unit, Department of Botany and Plant \\ Biology, University of Geneva, 1211, Geneva, \\ Switzerland. \\ ${ }^{8}$ Physics and Materials Science Research Unit, \\ University of Luxembourg, 162 A, Avenue de la \\ Faencerie, L-1511, Luxembourg City, Luxembourg.
}

\section{Summary}

Anoxygenic phototrophic sulfide oxidation by green and purple sulfur bacteria (PSB) plays a key role in sulfide removal from anoxic shallow sediments and stratified waters. Although some PSB can also oxidize sulfide with nitrate and oxygen, little is known about

Received 26 December, 2017; revised 23 January, 2019; accepted 24 January, 2019. *For correspondence. E-mail jasmine.berg@usys. ethz.ch; Tel. +41446336046. the prevalence of this chemolithotrophic lifestyle in the environment. In this study, we investigated the role of these phototrophs in light-independent sulfide removal in the chemocline of Lake Cadagno. Our temporally resolved, high-resolution chemical profiles indicated that dark sulfide oxidation was coupled to high oxygen consumption rates of $\sim 9 \mu \mathrm{M} \mathrm{O}_{2} \cdot \mathrm{h}^{-1}$. Single-cell analyses of lake water incubated with ${ }^{13} \mathrm{CO}_{2}$ in the dark revealed that Chromatium okenii was to a large extent responsible for aerobic sulfide oxidation and it accounted for up to $40 \%$ of total dark carbon fixation. The genome of Chr. okenii reconstructed from the Lake Cadagno metagenome confirms its capacity for microaerophilic growth and provides further insights into its metabolic capabilities. Moreover, our genomic and single-cell data indicated that other PSB grow microaerobically in these apparently anoxic waters. Altogether, our observations suggest that aerobic respiration may not only play an underappreciated role in anoxic environments but also that organisms typically considered strict anaerobes may be involved.

\section{Introduction}

Anoxygenic phototrophic bacteria oxidizing sulfide and fixing $\mathrm{CO}_{2}$ with sunlight play an important role in the carbon and sulfur cycles of sulfidic, shallow sediments and stratified water columns. Phototrophic sulfur bacteria, for example, are believed to be responsible for $20 \%-85 \%$ of the total daily carbon fixation in anoxic lakes (summarized in Cohen et al., 1977). This primary production is so important that it can control the bulk C-isotope fractionation in the water column, generating isotopic signatures that are transported and preserved in sediments (Posth et al., 2017). Biomass from anoxygenic phototrophs both feeds grazing zooplankton in overlying oxic waters (Sorokin, 1966) and drives sulfate reduction in anoxic waters below (Pfennig 1975). Phototrophic sulfur bacteria also remove toxic sulfide from the water column, enabling aerobic life at the surface while recycling sulfur compounds for sulfate reducers. While their role in sulfide detoxification has primarily been studied in stratified lakes, there are a few examples of marine environments such as the Black Sea (Jørgensen et al., 1991; Overmann et al., 1992; Manske et al., 2005; Marschall 
et al., 2010) and the Chesapeake Bay (Findlay et al., 2015) where phototrophic sulfur bacteria also significantly impact sulfur cycling.

Anoxygenic phototrophs generally inhabit illuminated, anoxic, reducing environments due to the toxicity of oxygen to these bacteria, and to the competition with abiotic reactions involving oxygen for their electron donors. Abiotic sulfide oxidation with oxygen is kinetically hampered and thus extremely slow (on the order of days) in trace-metal poor waters (e.g. Millero 1986; Millero et al. 1987; Luther et al. 2011). However, the presence of metals such as $\mathrm{Fe}$, and less importantly $\mathrm{Mn}$, has been shown to catalyze the reaction between sulfide and oxygen (Vazquez et al. 1989). Nonetheless, sulfide oxidation by microorganisms possessing enzymes which have evolved to overcome these kinetic constraints likely remains the most important sulfide removal process in most environments (Luther et al. 2011).

In fact, some anoxygenic phototrophs have evolved the capacity for chemotrophic growth under microoxic conditions. Whereas the green sulfur bacteria (GSB) of the Chlorobiaceae family are considered strict anaerobes, members of the Proteobacteria collectively known as the purple sulfur bacteria (PSB) can be facultatively microaerobic (e.g. Kampf and Pfennig, 1980; De Witt and Van Gemerden, 1990). Both the GSB and PSB are well adapted to fluctuating environmental conditions, synthesizing and accumulating storage compounds during periods of substrate/nutrient excess. The anoxygenic phototrophs are known to store zero-valent sulfur $\left(\mathrm{S}^{0}\right)$, polyphosphate, glycogen, and in the case of the PSB alone, poly3-hydroxyalkanoates (PHA) (Mas and Van Gemerden, 1995). The macromolecular structure and metabolism of these compounds have been intensely studied in laboratory pure cultures in order to understand conditions leading to their accumulation and breakdown. It has been suggested that glycogen may play a role in energy generation under dark conditions based on observations that cultured Chromatium sp. utilize glycogen to reduce stored sulfur, yielding sulfide and PHA (Van Gemerden, 1968).

Here, we investigated the role of anoxygenic phototrophic bacteria in dark sulfur cycling processes in Lake Cadagno, a permanently stratified lake with high sulfate concentrations of up to $1-2 \mathrm{mM}$ in the monimolimnion. Microbial reduction of sulfate produces large amounts of sulfide in the anoxic bottom waters (up to $~ 300 \mu \mathrm{M}$ ) and sediments $(>500 \mu \mathrm{M})$ which support dense populations of GSB and PSB in the photic zone. These bacteria heavily influence the chemistry of the lake, forming a chemocline of 1-2 $\mathrm{m}$ in thickness where sulfide and oxygen remain mostly non-detectable. The PSB Chromatium okenii is by far the most active of these bacteria, having been shown to play a disproportionately large role in inorganic carbon and ammonium assimilation despite their low abundances ( $<1 \%$ of total cell numbers) in the chemocline (Musat et al., 2008; Posth et al., 2017). In addition to their important contribution to light-driven sulfide oxidation, previous studies have shown that the anoxygenic phototrophic bacteria of Lake Cadagno remain active in the dark (Musat et al., 2008; Halm et al., 2009; Storelli et al., 2013). However, their mechanism of energy generation in the absence of light is not yet clear. We therefore combined high-resolution biogeochemical profiling with metagenomic analyses to gain an overview of possible light-independent metabolic processes impacting the sulfur biogeochemistry of Lake Cadagno. In addition to providing insights into the metabolism of anoxygenic phototrophic bacteria in situ, we present a model to explain the mechanism of dark sulfide oxidation in the chemocline of this meromictic lake.

\section{Results and discussion}

\section{Biogeochemistry of Lake Cadagno}

Lake Cadagno is characterized by an oxic mixolimnion and a sulfidic monimolimnion spatially separated from each other by a chemocline (defined by bold contour lines in Fig. 1A) free of detectable oxygen (detection limit 50-100 nM) and containing very little sulfide $(0-5 \mu \mathrm{M})$. In August 2015, oxygen disappeared just above the chemocline close to $12 \mathrm{~m}$ depth. The daytime increase in oxygen concentrations between 11 and $12 \mathrm{~m}$ depth denotes net photosynthesis and the night time decrease denotes net respiration (Fig. 1A). The permanent absence of oxygen in the chemocline indicated that oxygen was consumed both in the day and the night.

Steep gradients of sulfide diffusing into the chemocline varied independently of light-dark periods and the total sulfide concentration in the chemocline did not exceed $5 \mu \mathrm{M}$ at any time point. Because the lake is meromictic, these stratified conditions were also present during other sampling years (see Supporting Information Fig. S2 for 2013 and 2014 profiles). In 2015, the 0.5-1 $\mathrm{m}$ wide chemocline was located around 11-12 $\mathrm{m}$ depth, with the exact location varying over the day most likely due to the action of internal waves (Egli et al., 1998). In previous years, the chemocline was up to $2 \mathrm{~m}$ wide (Supporting Information Fig. S2) and remained completely sulfide-free in the light and dark. Conservative properties such as temperature and conductivity were constant throughout the chemocline in all years sampled (Supporting Information Fig. S1 and 2) indicating mixing of this zone (Sommer et al., 2017). Flat conductivity profiles revealed stronger mixing of the chemocline in 2013 and 2014 (Supporting Information Fig. S2) than in 2015 (Supporting Information Fig. S1) when the region of constant conductivity was reduced or absent.

Chr. okenii was the most significant microorganism in the chemocline both in terms of biomass, accounting for 

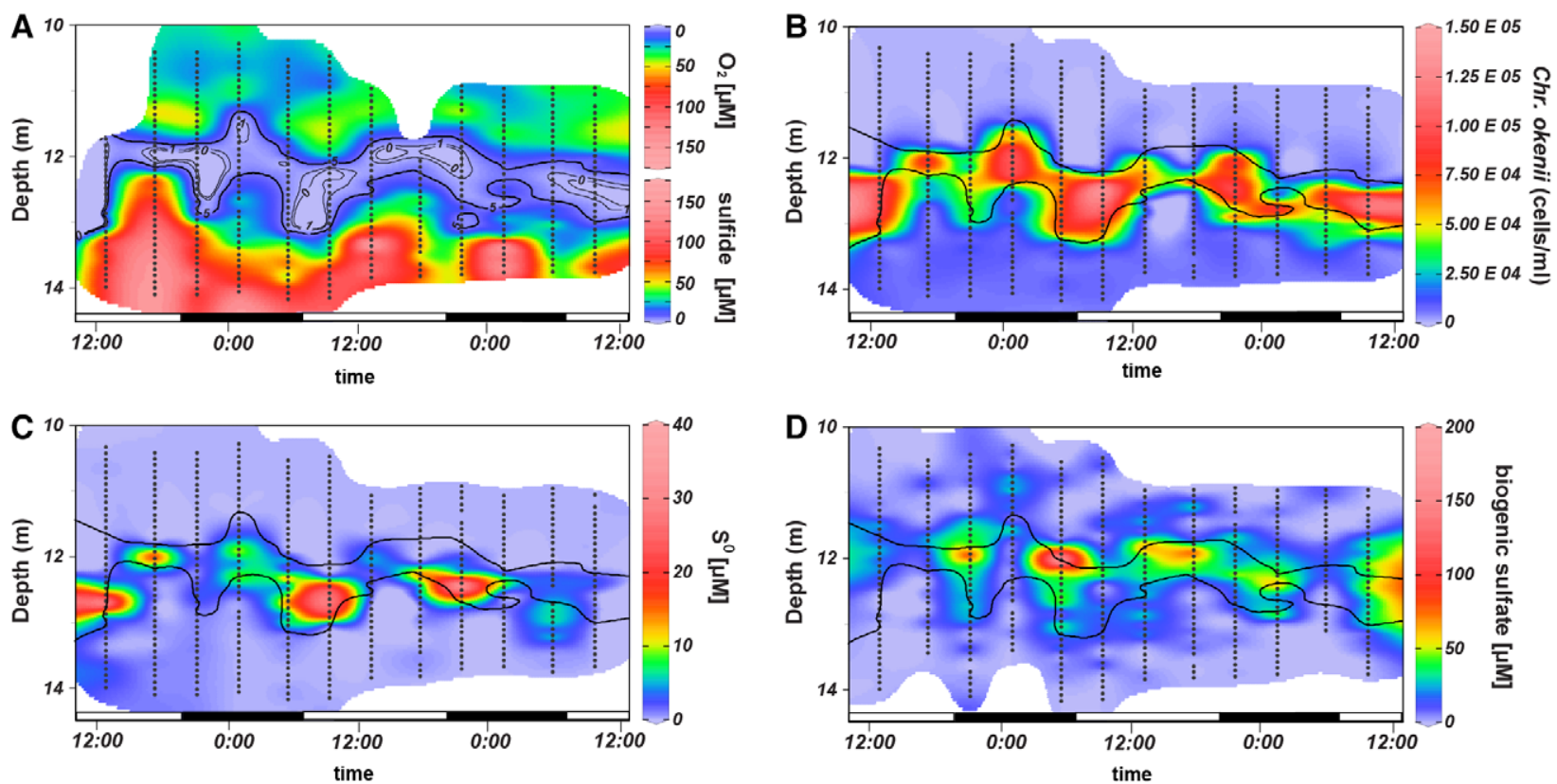

Fig. 1. A. Combined oxygen (top) and sulfide (bottom) profiles of the Lake Cadagno water column revealing the persistence of an oxygen- and sulfide- free zone over a period of $48 \mathrm{~h}$, with contour lines indicating sulfide concentrations. The bold contour lines delimiting the region with $>5 \mu \mathrm{M}$ sulfide were used to define the chemocline in parallel profiles of Chr. okenii cell counts (B), particulate $S^{0}(C)$ and sulfate (D). Black dots represent sampling points for all parameters except $\mathrm{O}_{2}$ which was measured with a microsensor mounted on a CTD probe. Shaded boxes represent dark periods between sunset at $\sim 20: 50$ and sunrise at $\sim 6: 10$. Time plots were interpolated from original profiles measured in August 2015 and are provided in Supporting Information Fig. S1. [Color figure can be viewed at wileyonlinelibrary.com]

$\sim 60 \%-80 \%$ of total microbial biovolume (Sommer et al. 2017), and activity, accounting for $30 \%-40 \%$ of inorganic carbon fixation (Supporting Information Fig. S3). The cell abundances of Chr. okenii in the Lake Cadagno chemocline were enumerated by flow cytometry during two daily cycles (Fig. 1B). Higher densities of Chr. okenii were found in $2014\left(10^{6} \cdot \mathrm{ml}^{-1}\right)$ than in $2015\left(10^{5} \cdot \mathrm{ml}^{-1}\right)$. Chr. okenii is highly motile, swimming at speeds of $\sim 27 \mu \mathrm{m} \cdot \mathrm{s}^{-1}$ and has been hypothesized to drive the convection and mixing of the chemocline (Wüest, 1994; Sommer et al., 2017). Chromatium are known to migrate between gradients of sulfide, light and oxygen by photo- and chemotaxis (Pfennig et al., 1968). We observed that Chr. okenii were positioned between oxygen and sulfide gradients, regardless of changes in depth or light availability (Fig. 1A and B). The hourly variations in cell numbers were likely the result of their heterogeneous distribution across the chemocline as Chr. okenii can swim in a horizontal direction or be displaced by compression of water masses by internal waves (Egli et al., 1998). Other anoxygenic phototrophs that have been consistently detected in the chemocline include the PSB Lamprocystis, Thiocystis and Thiodictyon and several GSB of the genus Chlorobium (Tonolla et al., 1999, 2004, 2005). Together these bacteria constituted the majority of the total phototrophic cells $\left(10^{6} \cdot \mathrm{ml}^{-1}\right)$ in 2015 , but they are considerably smaller in size (and thus proportion of total biovolume) than Chr. okenii.
The oxidation of sulfide by these anoxygenic phototrophs proceeds via the formation of $S^{0}$ as an obligate intermediate (Mas and Van Gemerden, 1995). This $S^{0}$ was measured as particulate sulfur on $0.7 \mu \mathrm{m}$ filters and may comprise $S^{0}$ stored intracellularly by $P S B$ and $S^{0}$ adhering extracellularly to GSB. The highest concentrations of $S^{0}$ (up to $45 \mu \mathrm{M}$; Fig. 1C) were measured in the middle of the chemocline. It is likely that this $S^{0}$ was present in the form of both elemental $S$ and polysulfides formed by the reaction of free sulfide with intracellular and extracellular $S^{0}$, as has previously been suggested in other euxinic lakes (Overmann, 1997). Our analytical method for total $\mathrm{S}^{0}$ did not distinguish between different forms of $\mathrm{S}^{0}$ such as cyclooctasulfur and polysulfides. However, we could confirm the presence of polysulfides inside live Chr. okenii cells in environmental samples using Raman spectroscopy. The Raman spectrum of a sulfur inclusion from Chr. okenii exhibited two weak peaks at 152 and 218 and a prominent peak at $462 \mathrm{~cm}^{-1}$ (Supporting Information Fig. S4) which is characteristic of linear polysulfide species (Janz et al., 1976). The Raman peak at $\sim 2900 \mathrm{~cm}^{-1}$ corresponds to the $\mathrm{CH}_{2}$ and $\mathrm{CH}_{3}$ stretching vibrations (Socrates, 2004), and its co-occurrence with polysulfide peaks support the theory that the sulfur chains in these purple sulfur bacteria are terminated by organic end groups as reported previously (Prange et al., 1999). 
Over two diurnal cycles, the $S^{0}$ inventory (Supporting Information Fig. S5A), or the total amount of particulate $S^{0}$ in the chemocline, was much lower than expected from the sulfide gradients and corresponding sulfide fluxes (discussed below), suggesting that stored $S^{0}$ served only as a transient intermediate and was rapidly oxidized to sulfate. No day-night trends in $\mathrm{S}^{0}$ accumulation were apparent in the chemocline. Nevertheless, the increase in the $S^{0}$ inventory at several time points during the night was indicative of dark sulfide oxidation.

In culture, Chromatium spp. are known to store carbon compounds like glycogen and polyhydroxyalkanoates (PHAs) which have been proposed to be involved in dark sulfur metabolism (Mas and Van Gemerden, 1995). We therefore quantified glycogen and PHA abundance in biomass samples from one day/night profile of the chemocline (Fig. 2A and B). We could not detect any PHA, but the presence of glycogen during the day and night coincided with Chr. okenii cell numbers (Fig. 2A and B). This is consistent with previous reports of glycogen storage and an absence of PHA in natural populations of Chr. okenii (Del Don et al., 1994). While the highest potential cellular glycogen content $\left(2.38 \cdot 10^{-6} \mu \mathrm{g} \mathrm{cell}^{-1}\right)$ was found at the top of the chemocline during the day, we observed little change in the cellular glycogen content between day and night (Supporting Information Fig. S6). Average potential cellular glycogen decreased from
$5.50 \cdot 10^{-7} \mu \mathrm{g} \mathrm{cell}{ }^{-1}$ during the day to $5.33 \cdot 10^{-7} \mu \mathrm{g}$ cell $^{-1}$ during the night, which represents a $3 \%$ reduction in cellular glycogen reserves. Chr. okenii in Lake Cadagno were previously reported to decrease their glycogen reserves by $50 \%$ in the dark (Del Don et al., 1994), but this may have been a result of undersampling as our time- and depth-resolved biogeochemical profiles revealed light-dark independent variations in Chr. okenii cell numbers and glycogen concentrations. While it has been demonstrated that Chromatium sp. in pure cultures obtain energy from the reduction of $S^{0}$ with glycogen in the dark (Van Gemerden, 1968), we could not confirm this observation for Chr. okenii in situ. From our data, we conclude that storage compounds did not play a significant role in the dark respiratory metabolism of Chr. okenii in the Lake Cadagno chemocline.

Sulfate was measured as the end-product of sulfide oxidation, but due to the high (1-2 mM) background sulfate concentrations, the comparably small concentration changes resulting from sulfide oxidation processes were non-detectable. To identify regions of sulfate production in and around the chemocline, we therefore determined deviations from the sulfate-conductivity mixing line drawn for each profile (see Supporting Information Fig. S7 for details). Strong mixing of the chemocline is expected to produce a linear relationship between sulfate and conductivity, and large digressions from this best-fit line
A

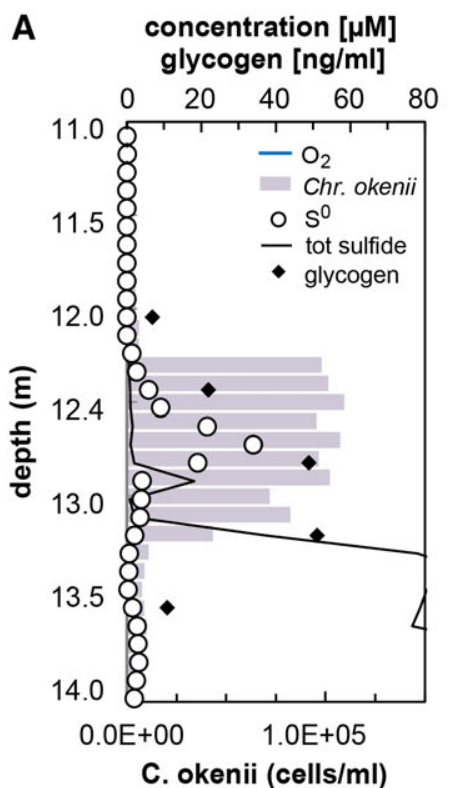

B
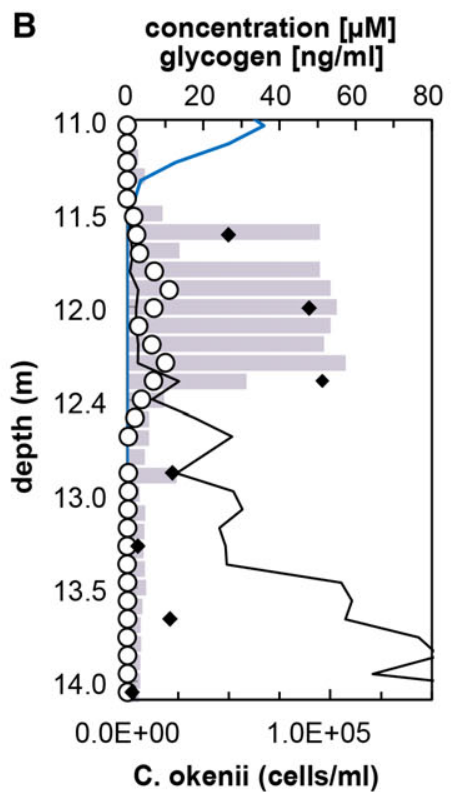

C

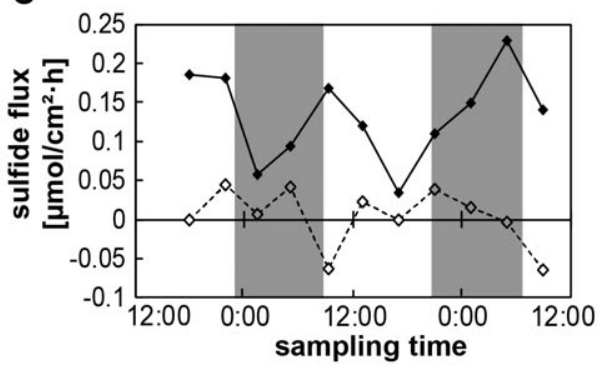

D

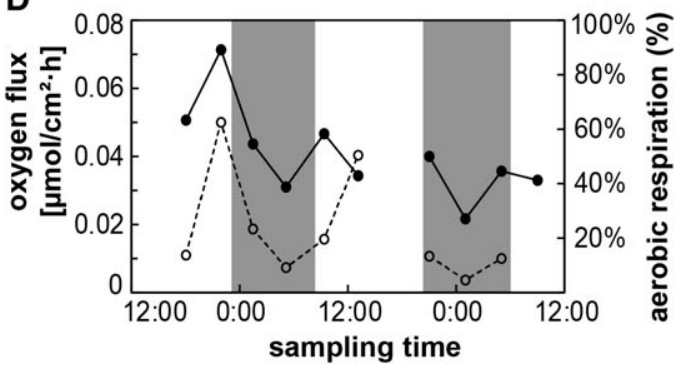

Fig. 2. Representative day (A) and night (B) profiles through the chemocline illustrating glycogen and $\mathrm{S}^{0}$ concentrations in relation to Chr. okenii cell numbers, oxygen and sulfide gradients in August 2015. No oxygen data are available for the day profile. Profiles were measured at $4 \mathrm{~h}$ intervals over two day-night cycles and used to calculate chemical fluxes. (C) The consumed sulfide flux (solid line) was calculated by subtracting the residual sulfide flux (dashed line) from the total sulfide flux into the mixed layer. (D) The downwards oxygen flux into the chemocline (solid line) was used to estimate the maximum \% of sulfide aerobically respired (dotted line), assuming the complete oxidation of sulfide to sulfate. Shaded regions represent dark periods. [Color figure can be viewed at wileyonlinelibrary.com] 
indicated that sulfate was produced faster than the rate of mixing. The expected sulfate concentration could be extrapolated based on measured conductivity, and then subtracted from the measured sulfate concentration to give excess sulfate:

measured $\left[\mathrm{SO}_{4}{ }^{2-}\right]-$ expected $\left[\mathrm{SO}_{4}{ }^{2-}\right]=\operatorname{excess}\left[\mathrm{SO}_{4}{ }^{2-}\right]$

This excess sulfate was attributed to biological sulfate production, as abiotic sulfide oxidation has been shown to produce mainly $\mathrm{S}^{0}$ and thiosulfate both in laboratory solutions (Chen and Morris 1972; Gourmelon et al. 1977 ) and in similarly stratified natural environments (Zopfi et al., 2001; Ma et al., 2006). Biogenic sulfate profiles from 2015 plotted over two diurnal cycles exhibited a peak at the top of the chemocline in the region of oxygen depletion (Fig. 1D). Interestingly, sulfate production was observed during the night and the overlap of excess sulfate and oxygen in these profiles indicated that sulfide may be oxidized aerobically. Daytime sulfate production in 2014 was related to photosynthetically active radiation (PAR) intensity (Supporting Information Fig. S2), suggesting that sulfide and $S^{0}$ could either have been oxidized aerobically within the chemocline using in situ-produced oxygen (Milucka et al., 2015) or phototrophically. The comparatively broad biogenic sulfate peak in the 2014 night profile likely reflects the broader vertical distribution of the Chr. okenii population (Supporting Information Fig. S2).

The sulfate excess in the chemocline is not expected to be affected by sulfate reduction as no sulfate reduction was detected within the chemocline in 2014 or 2015. The sulfate reduction rates measured in the sulfidic zone $1 \mathrm{~m}$ below the chemocline were about $235 \mathrm{nM} \cdot \mathrm{d}^{-1}$ and $375 \mathrm{nM} \cdot \mathrm{d}^{-1}$ in 2014 and 2015 respectively.

To quantify biological sulfide consumption over time, we calculated the total sulfide flux into the chemocline (Supporting Information Fig. S5B). Assuming that phototrophic sulfide oxidation ceases in the dark, upwardsdiffusing sulfide should accumulate in the chemocline at night. The expected sulfide accumulation was calculated based on fluxes into the layer over a $10 \mathrm{~h}$ night period and compared with the actual sulfide concentration observed in the layer. From an average sulfide flux $F=0.15 \mu \mathrm{m} \cdot \mathrm{cm}^{-2} \mathrm{~h}^{-1}$ (Supporting Information Fig. S5B), into a well-mixed layer of thickness $H=1 \mathrm{~m}$ over $t=10 \mathrm{~h}$, the resulting sulfide concentration $C=F^{*} t / H$ should be about $15 \mu \mathrm{M}$ in the chemocline. However, the average sulfide measured in the layer did not exceed $3 \mu \mathrm{M}$ (Fig. 1A), or five times less than expected, indicating that sulfide was consumed.

We therefore partitioned the total sulfide flux into two fractions: the flux of biologically consumed sulfide and the flux of residual sulfide in the chemocline. First, the amount of residual sulfide was calculated at each sampling time point by integrating sulfide concentrations within the mixed layer (Supporting Information Fig. S5C). The rate of sulfide accumulation was then calculated for each $4 \mathrm{~h}$ sampling interval and subtracted from the total sulfide flux to give the biologically consumed sulfide flux. The flux of sulfide consumed in the dark was in the same range as in the day $\left(0.03-0.22 \mu \mathrm{mol} \cdot \mathrm{cm}^{-2} \mathrm{~h}^{-1}\right)$ and the residual sulfide flux was very small in comparison (Fig. 2C). The observed variations did not correlate with day-night cycles and the changes of sulfide gradients could have been induced by internal waves, as mentioned above. Together, this indicates that sulfide oxidation continued in the dark and seemed to be related to the total sulfide flux (Supporting Information Fig. S5 B) rather than the presence of sunlight. For comparison, the upwards flux of sulfide in previous years was slightly lower, or $0.011-0.024 \mu \mathrm{mol} \cdot \mathrm{cm}^{-2} \mathrm{~h}^{-1}$ in 2013 and 0.032 $0.072 \mu \mathrm{mol} \cdot \mathrm{cm}^{-2} \mathrm{~h}^{-1}$ in 2014.

It was not possible to calculate $S^{0}$ fluxes in Lake Cadagno because $S^{0}$ is actively transported by the motile purple sulfur bacteria during chemo- and phototaxis (Pfennig et al., 1968) independent of diffusive processes. The total (upwards and downwards) biogenic sulfate flux (Supporting Information Fig. S5 D) in this region was roughly equivalent to the sulfide flux and followed a similar trend.

Overall, our high-resolution profiles revealed that sulfide in Lake Cadagno was consumed during the day and night, but only light-dependent sulfide oxidation has thus far been recognized as a major sulfide-removing process in the lake. In the absence of light, it is also possible that alternative electron acceptors such as $\mathrm{NO}_{x}^{-}, \mathrm{Fe}^{(\mathrm{III})}, \mathrm{Mn}^{(\mathrm{IV})}$ or $\mathrm{O}_{2}$ play a role in sulfide oxidation. Nitrate and nitrite concentrations in the Lake Cadagno chemocline are negligible (Halm et al., 2009; Milucka et al., 2015). High fluxes of reduced, dissolved metals $\left(0.027 \mu \mathrm{mol} F \cdot \mathrm{cm}^{-2} \cdot \mathrm{d}^{-1}\right.$ and $\mathrm{Mn} 0.049 \mu \mathrm{mol} \mathrm{Mn} \cdot \mathrm{cm}^{-2} \cdot \mathrm{d}^{-1}$ ) suggest that Fe- and $\mathrm{Mn}$-oxides are rapidly reduced by microorganisms or abiotically by sulfide in the chemocline (Berg et al., 2014), but re-oxidation of $\mathrm{Fe}$ and $\mathrm{Mn}$ would ultimately depend on oxygen in the dark. We therefore considered oxygen as the principal direct (or indirect) oxidant responsible for observed dark sulfide oxidation.

The oxygen flux into the chemocline varied slightly between 0.022 and $0.071 \mu \mathrm{mol} \cdot \mathrm{cm}^{-2} \mathrm{~h}^{-1}$ over the period of $48 \mathrm{~h}$ (Fig. 2D). Oxygen fluxes measured in 2013 and 2014 were in the same range, or $0.013-0.048 \mu \mathrm{mol} \cdot \mathrm{cm}^{-2} \mathrm{~h}^{-1}$ and $0.037-0.073 \mu \mathrm{mol} \cdot \mathrm{cm}^{-2} \mathrm{~h}^{-1}$ respectively.

Sulfide oxidation can occur in two steps:

1. $\mathrm{O}_{2}+2 \mathrm{HS}^{-}+2 \mathrm{H}^{+} \rightarrow 2 \mathrm{~S}^{0}+2 \mathrm{H}_{2} \mathrm{O}$

2. $2 \mathrm{~S}^{0}+3 \mathrm{O}_{2}+\mathrm{H}_{2} \mathrm{O} \rightarrow 4 \mathrm{H}^{+}+2 \mathrm{SO}_{4}{ }^{2-}$ 
Assuming that all sulfide is eventually oxidized to sulfate, we related oxygen fluxes to sulfide consumption using the 2:1 stoichiometry for complete aerobic sulfide oxidation:

3. $2 \mathrm{O}_{2}+\mathrm{HS}^{-} \rightarrow 1 \mathrm{H}^{+}+\mathrm{SO}_{4}{ }^{2-}$

Calculated oxygen fluxes in 2013 and 2014 were sufficient to account for all the sulfide oxidized in the dark. In 2015, aerobic sulfide respiration could account for up to $10 \%-50 \%$ of sulfide oxidized during the day and $5 \%-45 \%$ of sulfide oxidized during the night (Fig. 2D). During the day, it is likely that the remainder of sulfide oxidation is accounted for by anoxygenic photosynthetic sulfur bacteria (Fig. 3E) and aerobic sulfide oxidation fuelled by in situ oxygen production by active photosynthetic algae (Fig. 3D and Supporting Information Fig. S10; See also Milucka et al. 2015). At several time points in the dark, however, we could not explain the disappearance of roughly $60 \%-$ $90 \%$ of upwards-diffusing sulfide. We hypothesize that the missing oxygen is supplied laterally from the turbulent transport initiated by internal wave breaking at the lake boundaries. The convection within the chemocline may be key to the transport of oxygen and sulfide to aerobic sulfide-oxidizing bacteria in the chemocline. A weakening of the mixing regime was observed in August 2015 (Sommer et al., 2017) which may have signified a slowed transport of electron acceptors, thus contributing to the accumulation of sulfide in the chemocline.

To determine potential $\mathrm{O}_{2}$ consumption rates in the Lake Cadagno chemocline, we performed incubation experiments with chemocline water by sequentially injecting dissolved $\mathrm{O}_{2}$ and $\mathrm{H}_{2} \mathrm{~S}$ and monitoring $\mathrm{O}_{2}$ concentrations online (Supporting Information Fig. S8). Background rates of $\mathrm{O}_{2}$ consumption prior to $\mathrm{H}_{2} \mathrm{~S}$ addition were 0.55-0.57 $\mu \mathrm{M} \cdot \mathrm{h}^{-1}$ (Supporting Information Fig. S8 B). Within $5 \mathrm{~min}$ of $\mathrm{H}_{2} \mathrm{~S}$ addition, the $\mathrm{O}_{2}$ consumption rate increased fourfold to fivefold and remained high for 15-30 min. The response of the $\mathrm{H}_{2} \mathrm{~S}$ addition was highly reproducible, resulting in mean rates of $8.7 \pm 1.9 \mu \mathrm{M}$ $\mathrm{O}_{2} \cdot \mathrm{h}^{-1}$ for five consecutive additions (Supporting Information Fig. S8 B). These potential aerobic respiration rates were well within the range of the volumetric oxygen consumption rates $\left(4.4-14.2 \mu \mathrm{M} \mathrm{O}_{2} \cdot \mathrm{h}^{-1}\right)$ determined from in situ fluxes over a chemocline of $0.5 \mathrm{~m}$ thickness.

For each injection of $1.6 \mu \mathrm{M} \mathrm{H} \mathrm{H}_{2} \mathrm{~S}, \mathrm{O}_{2}$ concentrations fell by $1.5-2.5 \mu \mathrm{M}$ which is equivalent to a stoichiometry of $\mathrm{O}_{2}$ : $\mathrm{H}_{2} \mathrm{~S}$ between $1: 1$ and 2:1. This suggests a combination of sulfide oxidation to sulfur, potentially incorporated into storage granules, and to sulfate (Eqs. 1 and 3). Between sulfide additions, the background oxygen consumption rates were slightly increased (Supporting Information Fig. S8C),
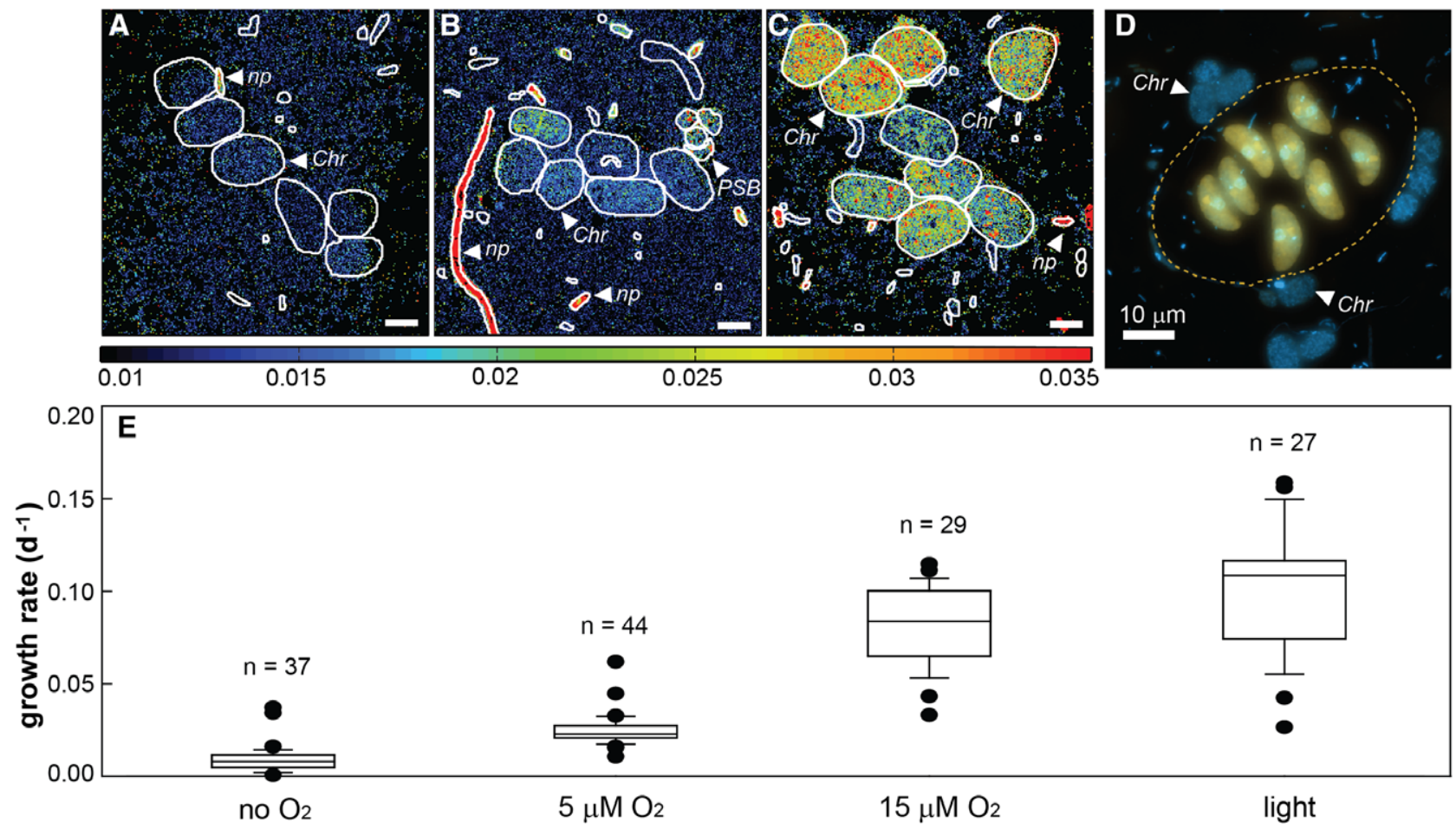

0.02
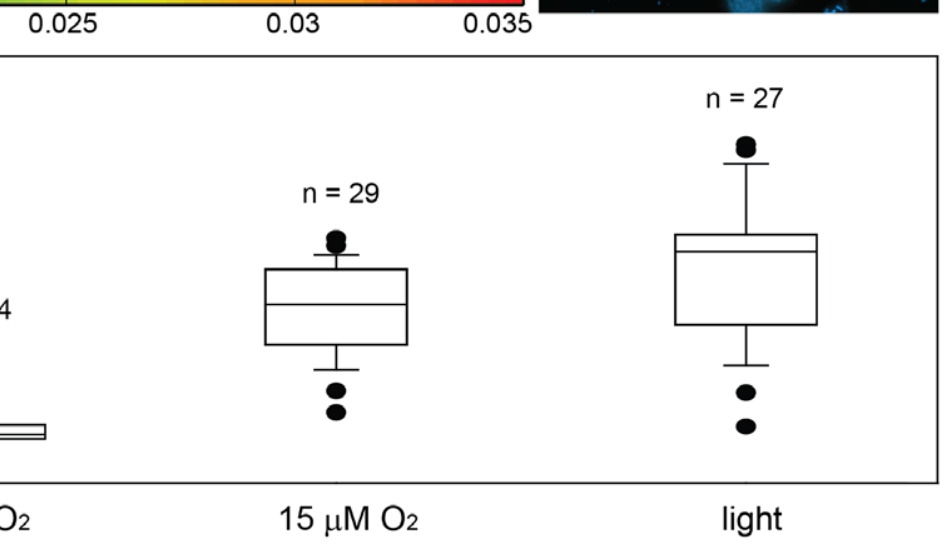

Fig. 3. ${ }^{13} \mathrm{CO}_{2}$ uptake by individual Chr. okenii cells incubated in the dark with no $\mathrm{O}_{2}, 5 \mu \mathrm{M}$ (expected) dissolved $\mathrm{O}_{2}$ and $15 \mu \mathrm{M}$ (expected) $\mathrm{O}_{2}$, and in the light with no added $\mathrm{O}_{2}$. Secondary ion images $\left(\mathrm{A}-\mathrm{C}\right.$ ) show ratios of ${ }^{13} \mathrm{C} /{ }^{12} \mathrm{C}$. Scale bars are $3 \mu \mathrm{m}$ and bacterial cells are outlined in white. Epifluorescence microscopy image (D) of DAPI-stained Chr. okenii associated with a consortium of autofluorescent algal cells enclosed within an organic sheath (dotted orange line, defined based on ${ }^{12} \mathrm{C}^{14} \mathrm{~N}$ image in Supporting Information Fig. S8). White triangles denote cells identified as: $\mathrm{Chr}=\mathrm{Chr}$. okenii, $\mathrm{PSB}=$ other purple sulfur bacteria and $\mathrm{np}=$ non-phototrophic.E. Box-and-whisker plots showing the range and the median growth rate of Chr. okenii under each incubation condition calculated from ${ }^{13} \mathrm{C}$-uptake per cell. [Color figure can be viewed at wileyonlinelibrary.com] 
likely due to the oxidation of stored sulfur to sulfate. Based on the experimental oxygen consumption rate, we calculated the most conservative sulfide oxidation rate (using a 2:1 ratio) to be $4.35 \mu \mathrm{M} \mathrm{H}_{2} \mathrm{~S} \cdot \mathrm{h}^{-1}$. Further isotope incubation experiments were conducted (below) to confirm that microorganisms, rather than abiotic processes, play a key role in aerobic sulfide oxidation in Lake Cadagno.

\section{Dark activity of Chr. okenii in Lake Cadagno}

While the sulfide-oxidizing Chr. okenii is one of the most active microorganisms in the Lake Cadagno chemocline in terms of C-fixation in the light (Musat et al. 2008; Supporting Information Fig. S3), its metabolic activity and contribution to sulfide removal in the dark has not yet been investigated. The capacity for microaerophilic respiration is known for a few PSB, and it is therefore possible that Chr. okenii grows chemoautotrophically on oxygen and sulfide in the absence of light. To test this, we incubated Lake Cadagno chemocline water with added sulfide and ${ }^{13} \mathrm{CO}_{2}$ in the dark under anoxic, low microoxic and medium microoxic conditions and compared the C-fixation activity of single Chr. okenii cells to that under light conditions. In order to mimic the diffusive flux of $\mathrm{O}_{2}$ in the lake, air was injected into the headspace of the microoxic incubations to achieve expected concentrations of $5 \mu \mathrm{M}$ and $15 \mu \mathrm{M}$ dissolved $\mathrm{O}_{2}$ in the low and medium incubations, respectively. Although bottles were shaken at the start of the incubation to equilibrate the water and headspace and then stirred constantly to enhance diffusion of $\mathrm{O}_{2}$ into the water, dissolved $\mathrm{O}_{2}$ concentrations dropped rapidly within the first hour of incubation (Supporting Information Fig. S9A and B) at the same rate $\left(8 \mu \mathrm{M} \mathrm{O}_{2} \cdot \mathrm{h}^{-1}\right)$ observed in our experimental rate measurements above. For the remainder of the incubation, dissolved $\mathrm{O}_{2}$ remained below $15 \%$ of the targeted concentrations, most likely because $\mathrm{O}_{2}$ consumption outpaced diffusion resulting in $\mathrm{O}_{2}$ concentrations close to those observed in situ.

The incorporation of ${ }^{13} \mathrm{CO}_{2}$ into $\mathrm{Chr}$. okenii cells under dark, anoxic conditions was only slightly above background (Fig. 3A). The mean growth rate of $0.009 \pm 0.007$ $\mathrm{d}^{-1}$ could be attributed to trace oxygen contamination or to fermentation of carbon storage compounds as reported by Van Gemerden (1968). A few small rod-shaped cells were also enriched in ${ }^{13} \mathrm{C}$ and were likely sulfurdisproportionating bacteria such as Desulfocapsa and Desulfobulbus which have previously been identified in Lake Cadagno (Tonolla et al. 2000; Peduzzi et al. 2003). In the microoxic incubations, dark C-fixation activity of Chr. okenii increased proportionally with the amount of $\mathrm{O}_{2}$ added (Fig. 3B and C) confirming that these bacteria obtained energy from aerobic respiration. The mean growth rate at an expected concentration of $15 \mu \mathrm{M} \mathrm{O}_{2}$ $\left(0.082 \pm 0.021 \mathrm{~d}^{-} 1\right)$ was about three times higher than at an expected concentration of $5 \mu \mathrm{M} \mathrm{O}_{2}(0.025 \pm 0.008$ $\mathrm{d}^{-1}$ ). Based on these growth rates and total cell abundances, we could estimate that Chr. okenii accounted for $31 \%-42 \%$ of the dark C-assimilation measured by bulk analyses (Supporting Information Fig. S3).

Clusters of cells reminiscent of the PSB Thiodictyon as well as a few other bacterial filaments and rod-shaped cells that were most likely aerobic, sulfide-oxidizing bacteria were also highly enriched in ${ }^{13} \mathrm{C}$ (Fig. 3B and C). This suggests that the capacity for aerobic respiration is taxonomically widespread in the anoxic chemocline.

Surprisingly, Chr. okenii growth rates in the light and without added oxygen $(0.100 \pm 0.033)$ were only slightly higher than under microoxic conditions (Fig. 3E) and their activity represented about $25 \%$ of the total C-assimilation (Supporting Information Fig. S3). Since this incubation was performed over a full light-dark cycle, it is also possible that activity was restricted to the $13 \mathrm{~h}$ light period, which would yield a higher hourly growth rate. While it is difficult to disentangle phototrophic from chemoautotrophic carbon fixation in this case, the presence of abundant associations of Chr. okenii cells with eukaryotic algae (Fig. 3D) indicates that these PSB can also thrive off local light-driven $\mathrm{O}_{2}$ production. We could show that algae were photosynthetically active via the incorporation of ${ }^{13} \mathrm{CO}_{2}$ into the eukaryotic cells (Supporting Information Fig. S10). Diffusion of $\mathrm{O}_{2}$ to attached Chr. okenii cells may have stimulated chemoautotrophic growth as they were also highly enriched in ${ }^{13} \mathrm{C}$.

Chr. okenii use energy from aerobic respiration not only for anabolic processes but for motility as well. We could confirm that Chr. okenii are highly motile both in the day and the night by performing dark field video microscopy (see Movie S1 in Supplementary Materials) of environmental samples obtained during the night and monitored in a dark room to avoid light-induced artefacts. Although the average night time swimming speed of Chr. okenii $\left(9.9 \mu \mathrm{m} \mathrm{s}^{-1}\right.$; see Supporting Information Fig. S11) was a third of the day time swimming speed $\left(27 \mu \mathrm{m} \mathrm{s}^{-1}\right.$; Sommer et al. 2017), it is clear that Chr. okenii remains motile even under dark conditions. This motility may in fact be key to bridging spatially separated gradients of oxygen and sulfide on which they grow.

\section{Metagenomic insights into the Chr. okenii population in Lake Cadagno}

To assess the genomic potential for light-independent, aerobic sulfide oxidation by Chr. okenii in Lake Cadagno, we sequenced two metagenomes, one from the chemocline and one from a phototrophic, sulfide-oxidizing enrichment culture obtained from the lake (Supporting Information Table S1). From a combined metagenomics assembly, we 


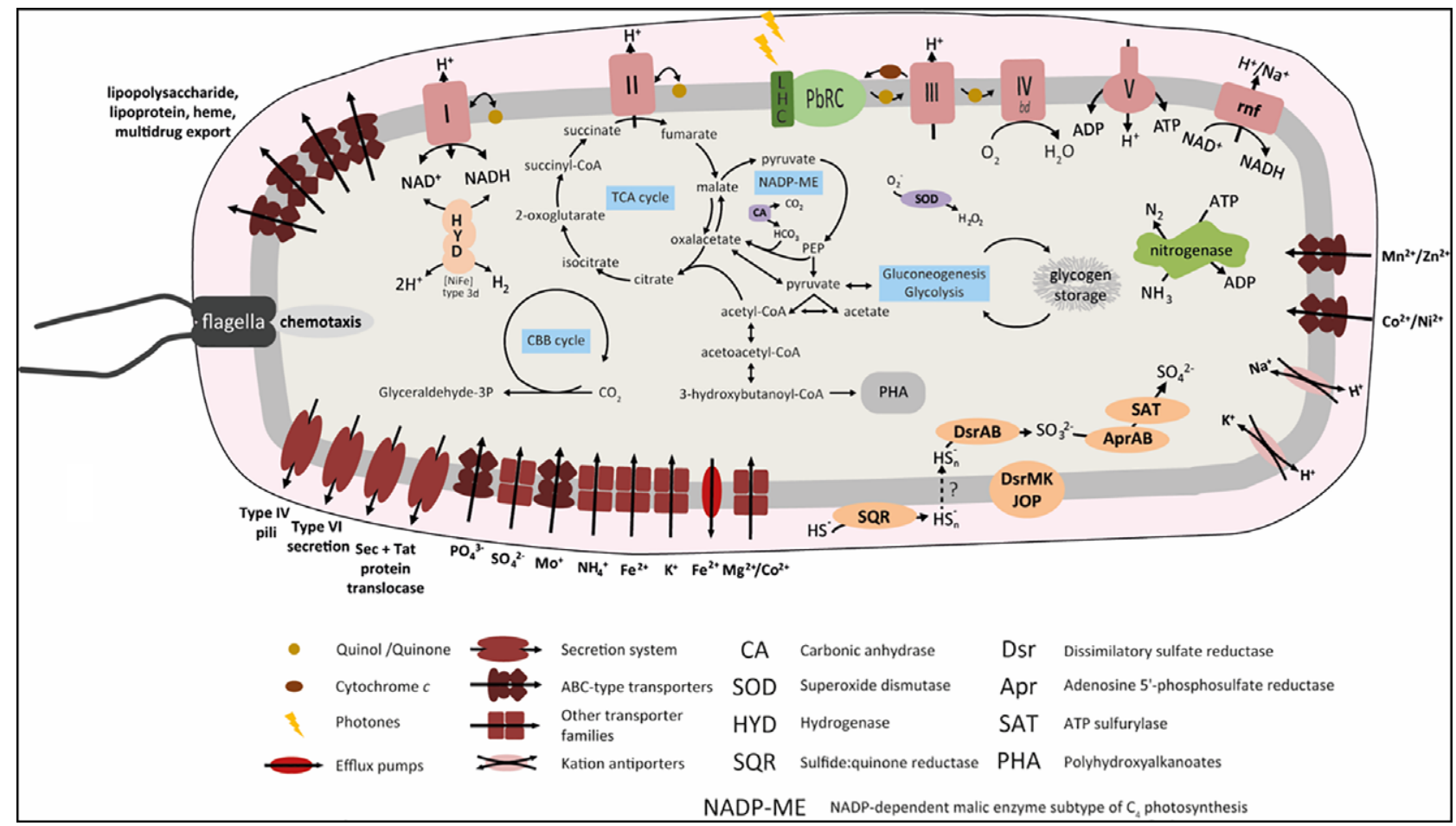

Fig. 4. Chr. okenii cell illustration, showing the metabolic potential inferred from the metagenome-assembled genome with a particular focus on the genetic machinery implicated in photosynthesis, sulfur oxidation, aerobic metabolism, motility, glycogen and PHA storage, nitrogen fixation and transmembrane transport.The respiratory chain enzyme complexes are labelled with Roman numerals. [Color figure can be viewed at wileyonlinelibrary.com]

reconstructed a high quality $(90 \%$ complete, $<1 \%$ contaminated) metagenome-assembled genome (MAG) of a PSB highly abundant in the sulfur-oxidizing enrichment culture (Supporting Information Fig. S12). The recovered MAG had a low average nucleotide identity ANI $(<70 \%)$ to any sequenced Chromatiaceae genomes (data not shown). However, it encoded an rRNA operon, including a complete 16S rRNA gene with $99 \%$ sequence identity to the $16 \mathrm{~S}$ rRNA gene of Chr. okenii (Imhoff et al., 1998; Tonolla et al., 1999), and thus likely represents a strain of Chr. okenii which is the type strain of the genus Chromatium. At this time, Chr. okenii has neither been successfully isolated in pure culture nor is there any published genome available for this organism.

The key metabolic process of Chr. okenii in Lake Cadagno is photoautotrophic sulfur oxidation. In accordance, the Chr. okenii MAG contained genes encoding for a sulfide: quinone reductase (sqr) and the full genomic inventory coding for a reverse-acting dissimilatory sulfite reductase (rDSR) pathway (Fig. 4). The operon structure of the rDSR encoding genes (dsrABEFHCMKLJOPN) was identical to the operon structure in the well described PSB model organism Allochromatium vinosum (Dahl et al., 2005), but no $d s r R$ and $d s r S$ gene were found. No genes encoding for sulfur oxidation via the SOX pathway, or homologues of sulfur globule proteins (sgpABC) typically found in PSB were detected in the draft genome. In line with its phototrophic metabolism, the Chr. okenii MAG showed the genomic potential for photosynthesis, with the genes encoding for a light harvesting complex 1 (pufAB) and a PSB-type photosynthetic reaction centre (pufLMC) encoded in a single operon. Furthermore, the full genomic repertoire for a NADP-Me type C4 photosynthetic carbon assimilation cycle, and all genes (with exception of $c b b S$ encoding for the small subunit of the ribulose1,5-bisphosphate carboxylase/oxygenase) necessary for $\mathrm{CO}_{2}$ assimilation via the Calvin-Benson-Bassham (CBB) cycle were present (Fig. 4).

Many Chromatiaceae can grow chemoautotrophically, respiring oxygen under microoxic conditions (Kampf and Pfennig, 1980). Cytochrome (Cyt) c-containing oxidases (e.g. Cyt aa3, Cyt cbb3) were not found in the Chr. okenii MAG. However, a Cyt bd type ubiqinol oxidase, known to function as sulfide-resistant $\mathrm{O}_{2}$-accepting oxidase in other Gammaproteobacteria (Forte et al., 2016), was identified (Fig. 4). Further, a plethora of genes related to heme $b$ ( $g / t X$, hemALBCD and hemH) and siroheme (cysG) synthesis, degradation (a heme oxygenase) and export (ABC-type heme exporter, $c c m A B C D$ ), as well as hemerythrin-like metal binding proteins were encoded. Hemerythrin has been implicated in binding of oxygen for delivery to oxygenrequiring enzymes, for detoxification or for oxygen sensing in motile, microaerobic prokaryotes (French et al., 2007). The presence of these oxygen-dependent enzymes, as well 


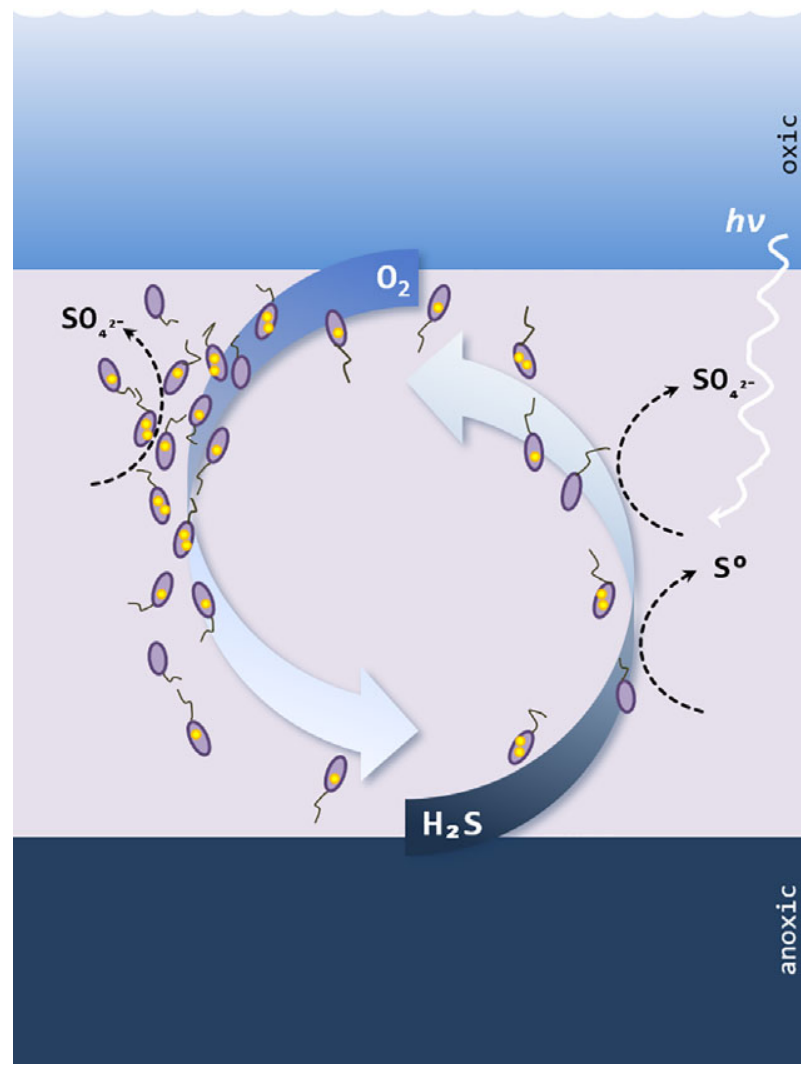

Fig. 5. Schematic of phototrophic and aerobic sulfide oxidation processes in the Lake Cadagno chemocline. Convection in the chemocline may be driven by a combination of turbulence and sinking bacterial plumes, represented by the large number of descending Chr. okenii cells on the left. As a result, oxygen and sulfide are entrained into the chemocline and immediately consumed by purple sulfur bacteria, keeping concentrations of these compounds below detection limits. Chr. okenii cells, depicted with internal sulfur globules (yellow dots), are pulled in the direction of their flagellar bundle. [Color figure can be viewed at wileyonlinelibrary.com]

as a key oxidative stress defence enzyme superoxide dismutase (SOD), support the idea that Chr. okenii may be facultatively microaerobic. A complete set of genes for flagellar biosynthesis (fliDEGHJKLMNOPQRW, flgABCDEF$G H I K, f l h A B)$ and flagellar motor proteins (motAB) confer motility to this bacterium.

Several other genes revealed interesting metabolic capacities of Chr. okenii. A cytosolic bidirectional [NiFe] type 3d hydrogenase and a nitrogenase were encoded in the MAG (Fig. 4), implicating the potential for involvement of Chr. okenii in nitrogen fixation and hydrogen oxidation which has previously been overlooked. Additionally, the Chr. okenii MAG encoded a glycogen synthase and a glycogen debranching enzyme, as well as the full genomic repertoire necessary for polyhydroxyalkanoate (PHA) biosynthesis. This is consistent with the detection of glycogen in our biogeochemical profiles of the chemocline. Finally, it is possible that novel terminal oxidases are among the hypothetical genes that could not be assigned any known function.

\section{Conclusions}

It is intriguing that oxygen should play a major role in sulfide oxidation in the ostensibly anoxic chemocline of Lake Cadagno, especially by purple sulfur bacteria generally thought to lead an anaerobic lifestyle. To explain the coupling of oxygen and sulfide consumption in the oxygen- and sulfide-free chemocline of Lake Cadagno, we sketched a diagram of the transport processes likely driving biological activity there (Fig. 5). As described in Sommer et al. (2017), active convection of the chemocline can be driven by the formation of sinking bacterial plumes. Combined with turbulence induced by the breaking of internal waves at the sides of the lake basin, these convective currents may entrain sulfide and oxygen at the boundaries of the chemocline and fuel populations of sulfide-oxidizing Chr. okenii there.

Sulfide-oxidizing bacteria have previously been reported to bridge distances between pools of electron donors and acceptors by intracellularly storing and transporting $\mathrm{S}^{0}$ and $\mathrm{NO}_{3}{ }^{-}$between redox zones (Fossing et al., 1995; Jørgensen and Gallardo, 1999) and even by transferring electrons along nanowires (Pfeffer et al., 2012), but aerobic sulfide oxidation in Lake Cadagno represents a new mechanism of electron acceptor/donor coupling across large distances. After entrainment into the chemocline, dissolved oxygen and sulfide are consumed so rapidly that they remain below detection limits. The physical and biological processes described here may therefore provide clues to sulfide oxidation in other anoxic environments such as the Black Sea where the mechanism of sulfide removal is not completely understood. Clearly, the biochemical limits to oxygen utilization are far below current definitions of anoxia and demonstrate that aerobic respiration is possible in socalled 'anoxic' lacustrine (Milucka et al., 2015) and marine (Garcia-Robledo et al., 2017) waters.

Although purple sulfur bacteria are generally considered anaerobes, we propose that Chr. okenii in the Lake Cadagno chemocline aerobically respire upwardsdiffusing sulfide in addition to performing phototrophic sulfide oxidation as previously reported (e.g. Tonolla et al. 1999; Musat et al. 2008; Storelli et al. 2013). Our direct evidence for oxygen-driven $\mathrm{C}$-fixation and continued motility of Chr. okenii in darkness is also supported by the presence of a potential high-affinity oxidase in the metagenome-assembled genome. In contrast to observations from laboratory cultures, Chr. okenii may have a very different metabolism in the environment where high fluxes of substrates rather than absolute substrate concentrations fuel microbial activity.

Our nanoSIMS measurements revealed that in addition to Chr. okenii, a number of phototrophic and nonphototrophic cells are also highly active under aerobic, sulfide-oxidizing conditions. Based on the diversity of genes encoding for high- $\mathrm{O}_{2}$ affinity terminal oxidases found in 
our Lake Cadagno metagenome, it appears that some other purple sulfur bacteria as well as a handful of Gamma- and Epsilonproteobacteria might aerobically oxidize sulfide (Supporting Information Fig. S13). Interestingly, two species of strictly anaerobic green sulfur bacteria from Lake Cadagno also possessed genes encoding for terminal oxidases, though further study will be required to elucidate the role of these different bacterial populations in chemotrophic sulfide oxidation.

\section{Experimental procedures}

\section{Sampling}

The meromictic Lake Cadagno is situated in the Piora Valley in the Swiss Alps at an altitude of $1921 \mathrm{~m}$. Data presented here were collected during field campaigns in September 2013, August 2014, June 2015, August 2015 and August 2018. In 2013 and 2014 in situ measurements were performed with a profiling ion analyser (PIA; see Kirf et al., 2014 for description) lowered from a platform anchored at the deepest part of the lake $(20.7 \mathrm{~m})$. Conductivity, turbidity, depth (pressure), temperature and $\mathrm{pH}$ were measured with a multiparameter probe (XRX 620, RBR). Dissolved oxygen was recorded online with a type PSt1 normal (detection limit $125 \mathrm{nM}$ ) micro-optode and a type TOS7 trace (reliable detection limit 50-100 nM) microoptode (PreSens). The oxygen sensors were calibrated by parallel Winkler titrations. Water samples for chemical analyses and cell counts were collected with a rosette syringe sampler equipped with twelve $60 \mathrm{ml}$ syringes triggered online at selected depths. Due to a technical failure of the PIA, the 6 AM profile in August 2014 and all subsequent profiles were measured with an SBE 19 plus V2 CTD probe (Sea-Bird Electronics) equipped with sensors for pressure, temperature and conductivity, and with additional sensors for turbidity (WET Labs Eco), oxygen (SBE 43), pH (18-I) and two fluorescence wavelengths (WET Labs ECO-AFL). The detection limit of the SBE 43 oxygen probe was about $1 \mu \mathrm{mol} \mathrm{I}^{-1}$. In parallel with in situ measurements, water for chemical analyses was pumped to the surface through Neoprene tubing attached to the CTD and filled into $60 \mathrm{ml}$ syringes (rinsed twice with in situ water) on board. Two parallel metal plates of diameter $\sim 15 \mathrm{~cm}$ attached to the submersed end of the tubing served to channel water horizontally, resulting in more discrete vertical profiling.

Water samples in syringes were aliquoted on board immediately after collection. Samples for sulfate analyses were filtered $(0.22 \mu \mathrm{m}$ pore size $)$ directly into sterile Eppendorf vials. Sulfide samples were fixed with $\mathrm{Zn}$-acetate to a final concentration of $0.1 \%(\mathrm{w} / \mathrm{v})$. Biomass was concentrated onto GF/F filters (Whatman) and stored at $-20^{\circ} \mathrm{C}$ for analyses of intracellularly stored elemental sulfur and organic carbon compounds. Water for dissolved inorganic carbon (DIC) analysis was filled into $12 \mathrm{ml}$ Exetainers (Labco Limited) and capped before injecting $100 \mu$ of saturated $\mathrm{HgCl}_{2}$ solution to terminate microbial activity. Biomass samples for determination of background ${ }^{13} \mathrm{C}$ in the particulate organic carbon (POC) were concentrated onto precombusted $\left(6 \mathrm{~h}\right.$ at $\left.600^{\circ} \mathrm{C}\right) \mathrm{GF} / \mathrm{F}$ filters. Samples for DNA analysis were collected from the chemocline in August 2014 by concentrating microbial cells on $0.22 \mu \mathrm{m}$ GTTPtype polycarbonate filters (Millipore) on site and freezing at $-20^{\circ} \mathrm{C}$ until further processing.

Additional water for cultivation and motility experiments was pumped directly from the chemocline into $1 \mathrm{~L}$ Duran bottles or $250 \mathrm{ml}$ serum bottles and sealed with butyl rubber stoppers without a headspace to maintain anoxic conditions.

\section{Chemical analyses}

Sulfide was measured using the colorimetric method of Cline (1969). Sulfate was measured on a 761 Compact ion chromatograph (Metrohm) equipped with a Metrosep A SUPP 5 column. Intracellular sulfur on filters was extracted by sonication in methanol for $15 \mathrm{~min}$ in an ice bath. Samples were analysed on an Acquity H-Class UPLC system (Waters Corporation) with an Acquity UPLC BEH C18 column coupled to a photodiode array (PDA) detector using UPLC-grade methanol as eluent. Data were acquired and processed using the Empower III software.

Intracellular glycogen was analysed following the procedures of the assay kit (MAK016, Sigma Aldrich). Briefly, cells were extracted by scraping them from GF/F filters and homogenizing in $200 \mu \mathrm{l}$ extraction buffer and centrifuged two times to clear the supernatant. The supernatant was analysed fluorometrically after incubation with enzyme mix and fluorescent peroxidase substrate. Intracellular PHA was analysed using the protocol from Braunegg et al. (1978). Hydrolyzation of the polymer and conversion to a methyl-ester of the monomeric hydroxyalkanoate fraction was done in acidified alcohol solution $\left(6 \% \mathrm{H}_{2} \mathrm{SO}_{4}\right.$ in methanol) and chloroform under heating $\left(100{ }^{\circ} \mathrm{C}, 2 \mathrm{~h}\right)$. After addition of water and phase separation, the organic phase was analysed with GC-MS (Agilent 7890B GC connected to Agilent 5977A MSD) to detect the methylhydroxyalkanoates using the following settings: Agilent $30 \mathrm{~m}$ DB-5-MS column, splitless injection of $1 \mu \mathrm{l}$, temperature program was $50^{\circ} \mathrm{C}$ for 1 min than heating $10^{\circ} \mathrm{C} \min ^{-1}$ until $120{ }^{\circ} \mathrm{C}$ followed by $45^{\circ} \mathrm{C} \mathrm{min}{ }^{-1}$ until $320{ }^{\circ} \mathrm{C}$ and hold for $5 \mathrm{~min}$. Benzoic acid was used as internal standard in each sample and quantification was done with pure polyhydroxybutyrate standard (Sigma Aldrich).

Sulfate reduction rates were measured by adding the radiotracer ${ }^{35} \mathrm{SO}_{4}{ }^{2-}(5 \mathrm{MBq})$ to anoxic lake water in $50 \mathrm{ml}$ glass syringes and incubated in the dark. A solution of unlabelled $\mathrm{Na}_{2} \mathrm{~S}$ was added to a final concentration of $\sim 50 \mu \mathrm{mol} . .^{-1}$ as a background sulfide pool in case of sulfide 
re-oxidation. At each sampling point, $10 \mathrm{ml}$ of sample was dispensed into $5 \mathrm{ml}$ of $20 \%$ (w/v) Zn-acetate. Reduced sulfur species (e.g. sulfur and sulfide as $\mathrm{ZnS}$ ) were separated out via the chromium distillation method described in Kallmeyer et al. (2004), and the radioactivity per sample was determined via scintillation counting (Packard 2500 TR).

\section{Confocal Raman spectroscopy}

In a glove box under 90:10 $\mathrm{N}_{2}-\mathrm{CO}_{2}$ atmosphere, a drop of fresh sample from the chemocline was mounted between two glass coverslips and sealed with electrical tape to prevent contact with air. A polysulfide solution containing $5.06 \mathrm{~g} \mathrm{Na}_{2} \mathrm{~S} \cdot 9 \mathrm{H}_{2} \mathrm{O}$ and $5.8 \mathrm{~g}$ elemental sulfur per $100 \mathrm{ml} \mathrm{H}_{2} \mathrm{O}$, with a final $\mathrm{pH}$ of 9.5 and sulfide concentration of $210 \mathrm{mM}$, was used as reference.

Measurements were conducted with an NTEGRA Spectra confocal spectrometer (NT-MDT) coupled to an inverted Olympus IX71 microscope. The excitation light from a $532 \mathrm{~nm}$ solid-state laser was focused on the sample through an Olympus 100X (numerical aperture [NA], 1.3) oil immersion objective. Raman scattered light was collected by an electron-multiplying charge-coupled device (EMCCD) camera (Andor Technology) cooled to $-70^{\circ} \mathrm{C}$. Spectra were recorded between 0 and $4500 \mathrm{~cm}^{-1}$ with a spectral resolution of $0.2 \mathrm{~cm}^{-1}$ and analysed with the NT-MDT software Nova_Px 3.1.0.0.

\section{Flux calculations}

Turbulent fluxes $(J)$ of sulfide, sulfur, sulfate and oxygen at the chemocline were calculated assuming steady state by applying Fick's first law: $J=-D \partial C / \partial x$. For sulfide, sulfate and oxygen, we used the turbulent diffusion coefficient $(D)$ of $1.6 \times 10^{-6} \mathrm{~m}^{2} \mathrm{~s}^{-1}$ from (Wüest, 1994) corresponding to turbulence at the Lake Cadagno chemocline boundaries. The change in concentration $(\partial C)$ was computed for each species over the depths with the steepest gradients. Oxygen and sulfide fluxes were determined for the regions immediately above and below the chemocline, defined as the zone of constant conductivity.

\section{Potential oxygen consumption rate measurements}

Potential $\mathrm{O}_{2}$ consumption rate measurements were conducted as described in Holtappels et al. (2014). Incubations were performed in $250 \mathrm{ml}$ Winkler bottles using trace oxygen sensor spots ( $65 \mathrm{~mm}$, TROXSP5, Pyroscience) glued to the inner glass wall and read from the outside using a four channel fibre-optic oxygen meter (FireStingO2, Pyroscience) recording the $\mathrm{O}_{2}$ concentration every $10 \mathrm{~s}$. The glass stopper of the Winkler bottle was pierced with a glass tube $(11 \mathrm{~cm}$ long, inner diameter $1.5 \mathrm{~mm}$ ), to allow for pressure compensation due to temperature-induced volume changes and to facilitate the addition of small amounts of reagents. Oxygen transport through this opening was limited by diffusion through a narrow passage over a long distance. Tests with degassed sterile water showed negligible $\mathrm{O}_{2}$ concentration changes of 3-25 $\mathrm{nM} \cdot \mathrm{d}^{-1}$ (figures available on request). Water inside the incubation bottles was gently mixed by small glass-coated magnets driven by an adjacent magnetic stirrer. The incubation bottles were placed in a temperature-controlled water bath set to $4.8^{\circ} \mathrm{C}$ $\left(+/-0.1^{\circ} \mathrm{C}\right)$. A two-point calibration of the trace optode spots was performed using degassed water to which a known amount of $\mathrm{O}_{2}$-saturated water was added through the glass tube.

Anoxic chemocline water was pumped onboard a sampling platform and distributed directly into incubation vessels via Neoprene tubing, avoiding atmospheric contamination as described above. Bottles were placed immediately into the water bath and incubated in the dark for $18 \mathrm{~h}$. Initial $\mathrm{O}_{2}$ values were between 6 and $8 \mu \mathrm{M}$. Over a period of $12 \mathrm{~h}$, sulfide was added five times by injecting up to $300 \mu$ of a $4 \mathrm{mM} \mathrm{Na} \mathrm{Na}_{2} \mathrm{~S}$ stock solution to a final concentration of $1.6 \mu \mathrm{M}$. Between 4 and $6 \mathrm{ml} \mathrm{O}_{2}$-saturated lake water from the same depth was periodically added to maintain $\mathrm{O}_{2}$ concentrations between 5 and $11 \mu \mathrm{M} . \mathrm{O}_{2}$ consumption rates were calculated from linear regressions over 10-30 min time intervals.

\section{Stable isotope incubations}

Serum bottles of $250 \mathrm{ml}$ containing Lake Cadagno chemocline water collected in August 2018 were bubbled for 10 min with $\mathrm{N}_{2}$ to remove any contaminant oxygen. Four different incubation conditions were set up to test microbial carbon fixation under the following conditions: no $\mathrm{O}_{2}+$ dark, no $\mathrm{O}_{2}+$ light, low $\mathrm{O}_{2}+$ dark and medium $\mathrm{O}_{2}+$ dark. To each of the dark incubations, $50 \mathrm{ml}$ of water was removed and replaced with $\mathrm{N}_{2}$ gas. Solutions of $\mathrm{Na}_{2} \mathrm{~S}$ and ${ }^{13} \mathrm{C}$-DIC were added to final concentrations of $25 \mu \mathrm{M}$ and $1 \mathrm{mM}$ (36-39 atom \%), respectively, except for the light incubation which received $200 \mu \mathrm{M}$ (8 atom $\%{ }^{13} \mathrm{C}$-DIC. Volumes of $0.918 \mathrm{ml}$ and $2.8 \mathrm{ml}$ air were added to the dark, aerobic incubations to achieve headspace $\mathrm{O}_{2}$ concentrations of 129 and $388 \mu \mathrm{M}$, respectively, resulting in expected dissolved $\mathrm{O}_{2}$ concentrations of 5 and $15 \mu \mathrm{M}$, respectively, at the start of the incubations (Garcia and Gordon, 1992). All bottles were gently shaken for several minutes to equilibrate the water and headspace and then placed in a $10^{\circ} \mathrm{C}$ water bath in the dark for $18 \mathrm{~h}$, except for the light condition which was incubated separately under natural light, $0.1 \%-2 \%$ incident daylight, for a full light-dark cycle. Equilibration with the headspace was enhanced throughout the incubation by stirring with glass-coated magnetic stir-bars at minimum speed. 
In order to verify the consumption of oxygen, two bottles prepared without ${ }^{13} \mathrm{C}$-DIC and injected with $0.918 \mathrm{ml}$ and $2.8 \mathrm{ml}$ of air were incubated in parallel with needle optodes (FirestingO2, Pyroscience) immersed in the liquid phase. Dissolved $\mathrm{O}_{2}$ concentrations were recorded every $3 \mathrm{~min}$ and are shown in Supporting Information Fig. S9.

At the end of the experiment, bottles were sacrificed for analysis of bulk and single-cell ${ }^{13} \mathrm{C}$ uptake. Water for ${ }^{13} \mathrm{C}$-DIC and ${ }^{13} \mathrm{C}$-POC was sampled as described above. For nanoSIMS, water samples were fixed with formaldehyde $(2 \% \mathrm{v} / \mathrm{v})$ overnight at $4{ }^{\circ} \mathrm{C}$ before filtering onto $0.2 \mu \mathrm{m} \mathrm{Au} / \mathrm{Pd}$-sputtered polycarbonate filters (Millipore) and stored at $-20^{\circ} \mathrm{C}$ until processing.

\section{Mass spectrometry isotope uptake analysis}

The labelling $\%$ of ${ }^{13} \mathrm{C}$-DIC was determined by diluting Hg-killed water 1:10 in MilliQ and transferring $3 \mathrm{ml}$ into a $12 \mathrm{ml}$ Exetainer with an $\mathrm{N}_{2}$ headspace. Samples were then acidified with the addition of $\sim 100 \mu$ l concentrated $\mathrm{H}_{3} \mathrm{PO}_{4}$ so the outgassed ${ }^{13} \mathrm{CO}_{2}$ could be analysed by cavity ring-down spectroscopy (G2201-i Picarro).

The incorporation of ${ }^{13} \mathrm{C}$ from ${ }^{13} \mathrm{CO}_{2}$ into biomass was measured by combustion of the particulate organic carbon fraction on GF/F filters. Filters were decalcified by incubation with $37 \%$ fuming $\mathrm{HCl}$ overnight, dried in an oven at $60^{\circ} \mathrm{C}$ and then packed into tin capsules for combustion analysis. The $\mathrm{C}$ isotopic composition was determined on an automated elemental analyser (Thermo Flash EA, 1112 Series) coupled to a Delta Plus XP IRMS (Thermo Finnigan).

\section{Nanometre-scale secondary ion mass-spectrometry}

Circular pieces (5 $\mathrm{mm}$ diameter) were punched out of the $\mathrm{Au} / \mathrm{Pd}$-sputtered filter and regions of interest were marked with a laser microdissection microscope (LMD) (DM $6000 \mathrm{~B}$, Leica Microsystems) before analysis with the nanoSIMS 50 I (Cameca) at the Max Planck Institute for Marine Microbiology in Bremen, Germany. For each field of view, the sample was presputtered with a primary $\mathrm{Cs}^{+}$beam of $300 \mathrm{pA}$, and then measured by rastering a primary $\mathrm{Cs}^{+}$ beam with a diameter of $<100 \mathrm{~nm}$ and a beam current between 1.0 and $1.5 \mathrm{pA}$ over the area. Secondary ion images of ${ }^{12} \mathrm{C}^{-},{ }^{13} \mathrm{C}^{-},{ }^{12} \mathrm{C}^{14} \mathrm{~N}^{-},{ }^{31} \mathrm{P}^{-}$and ${ }^{32} \mathrm{~S}^{-}$were recorded simultaneously using five detectors together with the secondary electron (SE) image ranging from $10 \times$ $10 \mu \mathrm{m}$ to $50 \times 50 \mu \mathrm{m}$ in size and corresponding to an image size of $256 \times 256$ and $512 \times 512$ pixels, respectively, using a dwell time of $1 \mathrm{~ms}$ per pixel. Up to 60 planes were recorded for each imaged area.

Images were processed using the Matlab-based Look@NanoSIMS software (Polerecky et al., 2012). Regions of interest (ROIs) were drawn around cells based on the
$12 \mathrm{C}_{14 \mathrm{~N}^{-}}$signal overlain on SE images and Chr. okenii cells were identified based on morphology, size and pigmentation in parallel light-microscope images. Cellular ${ }^{13} \mathrm{C}$ atm. \% was calculated from ${ }^{13} \mathrm{C} /{ }^{12} \mathrm{C}$ values of individual ROls. The background (cell-free polycarbonate filter) ${ }^{13} \mathrm{C}$ content was also evaluated in every field of view for comparison. Growth rates were calculated assuming a linear growth rate where one cell division results in a maximum of $1 / 2$ the labelling percentage:

$g=\left(\operatorname{atm} \%{ }^{13}\right.$ excess $_{\text {cells }} / 1 / 2$ atm $\%{ }^{13}$ C excess $\left._{\text {tot dissolved }}\right) / t_{\text {hours }}$

Cellular C-uptakes rates were calculated based on the relationship between biovolume and $\mathrm{C}$-content from Verity et al. (1992), assuming an average biovolume of spherocylinders cells of $65 \mu \mathrm{m}^{3}$ based on direct measurements of $70 \mathrm{Chr}$. okenii cells.

\section{Motility analysis}

Water samples containing Chr. okenii cells were collected under anoxic conditions from the chemocline during the night, protected from artificial light with aluminium foil, and analysed immediately on site. Motile cells were transferred via a degassed glass syringe to a sealed rectangular millimetric chamber (dimensions $20 \mathrm{~mm} \times 10 \mathrm{~mm} \times 2 \mathrm{~mm}$ ) prepared using glass slides separated by a $2 \mathrm{~mm}$ thick spacer, which provided an anoxic environment during motility characterization. Experiments were conducted in a dark room, and imaging was performed using the dark field microscopy mode at $25 \mathrm{fps}$, with the lowest intensity illumination. No transient response was observed right at the start of the imaging, and the swimming velocity remained steady throughout the duration of the measurements. This is in contrast to swimming behaviour at higher light intensities where the swimming cells exhibited a positive phototactic response (Sommer et al., 2017). We could therefore rule out a light-induced effect on motility at the minimum illumination level used for our measurements. Videos of swimming cells were acquired and subsequently analysed using the ImageJ Particle Tracker routine to obtain the coordinates of the cells (geometric centres) at each time interval. These were used to calculate the swimming speeds and extract the trajectories of individual cells.

\section{DNA extraction, sequencing and analysis}

Two metagenomes were sequenced: one from the chemocline and one from a phototrophic, sulfide-oxidizing enrichment from the lake. The enrichment culture was obtained by preparing agar-stabilized sulfide-gradient tubes as described in Schwedt et al. (2012) using sterilefiltered Lake Cadagno water amended with vitamins and 
trace elements as described for cultivation of purple sulfur bacteria (Eichler and Pfennig, 1988). After inoculation with water from the chemocline, cultures were incubated for approximately 3 months in indirect light at $15^{\circ} \mathrm{C}$ until development of a deep purple colour indicative of growth of PSB.

DNA was extracted from polycarbonate filters or a small volume of agarose culture with the Ultra Clean MoBio PowerSoil DNA kit (MoBio Laboratories, Carlsbad, CA, USA) according to the manufacturer's protocol with the following modification: the bead beating step was reduced to $30 \mathrm{~s}$ followed by incubation on ice for $30 \mathrm{~s}$, repeated $4 \times$. The DNA was gel-purified using SYBR Green I Nucleic Acid Gel Stain (Invitrogen) and the QIAquick Gel Extraction Kit (Qiagen) according to the accompanying protocols. DNA concentration was determined fluorometrically at $260 \mathrm{~nm}$, using the Qubit 2.0 Fluorometer and the Qubit dsDNA HS Assay KIT (Invitrogen) and sent to the Max Planck-Genome Centre (Cologne, Germany) for sequencing. The metagenome was sequenced (100 bp paired end reads) by Illumina HiSeq (Illumina Inc., USA) sequencing following a TruSeq library preparation. Metagenomic reads were adapter- and quality-trimmed (phred score 15, bbduk function of the BBMap package, https:// sourceforge.net/projects/bbmap/) and paired-end reads were de novo assembled with the uneven depth assembler IDBA-UD (Peng et al., 2012).

The metagenome assembly was binned based on tetranucleotide frequencies, differential coverage, taxonomic classification and conserved single-copy gene profiles with the Metawatt binning software (version 3.5.2; Strous et al., 2012). The completeness and contamination of the binned MAGs was evaluated with CheckM (Parks et al. 2014). The bulk metagenome and the MAG identified as Chr. okenii were automatically annotated in IMG (Markowitz et al. 2011), and the Chr. okenii MAG was manually screened for the presence of genes of interest to this study. Assembled data are available in IMG, under the IMG genome IDs 3300010965 (bulk assembly) and 2700988602 (Chr. okenii MAG).

Cytochrome $c$ and quinol oxidase subunit I and the cytochrome $b d$ oxidase subunit I proteins were extracted from the metagenome via Pfam motif search (PF00115 and PF01654 respectively), and manually inspected to exclude NO reductase subunit $I$ (NorB) proteins and proteins shorter than 100 aa prior to downstream analysis. A total of 130 out of 178 identified cytochrome $c$ and quinol oxidase subunit I proteins and 76 out of 82 recovered cytochrome bd oxidase subunit I proteins passed the manual curation step. For phylogenetic tree reconstruction, the manually vetted protein sequences and a selection of reference sequences recovered from NCBI were aligned using MAFFT (Katoh et al., 2002) and IQ-TREE was used to construct the phylogenetic tree with automated best model prediction and a total of 1000 bootstrap replicates (Trifinopoulos et al., 2016; Hoang et al., 2017). Thereafter, a selection of sequences closely related to known sulfur oxidizing microorganisms alongside the respective reference sequences were used for reconstruction of the phylogenetic trees presented in Supporting Information Fig. S11. The output files were uploaded to iTOL for visualization (Letunic and Bork, 2016).

\section{Acknowledgements}

We are grateful to the 2014 and 2015 Cadagno Field Expedition Teams from EAWAG and MPI Bremen for assistance in the field, and to the Alpine Biology Center Foundation (Switzerland) for use of its research facilities. We would especially like to thank Abiel Kidane and Sten Littman for help with nanoSIMS measurements as well as Nadine Rujanski, Gabriele Klockgether and Gaute Lavik for mass spectrometry analyses. Funding was provided by the International Max Planck Research School of Marine Microbiology, the Max Planck Society and the Deutsche Forschungsgemeinschaft (through the MARUM Center for Marine Environmental Sciences). A.S. was supported by the Human Frontier Science Program (Cross Disciplinary Fellowship, LT000993/2014-C).

\section{References}

Berg, J.S., Schwedt, A., Kreutzmann, A.-C., Kuypers, M.M., and Milucka, J. (2014) Polysulfides as intermediates in the oxidation of sulfide to sulfate by Beggiatoa spp. Appl Environ Microbiol 80: 629-636.

Braunegg, G., Sonnleitner, B.Y., and Lafferty, R.M. (1978) A rapid gas chromatographic method for the determination of poly- $\beta$-hydroxybutyric acid in microbial biomass. Appl Microbiol Biotechnol 6: 29-37.

Chen, K.Y., and Morris, J.C. (1972) Kinetics of oxidation of aqueous sulfide by oxygen. Environ Sci Technol 6: 529-537.

Cohen, Y., Krumbein, W. E., and Shilo, M. (1977) Solar Lake (Sinai). 2. Distribution of photosynthetic microorganisms and primary production1. Limnol Oceanogr 22: 609-620.

Cline, J.D. (1969) Spectrophotometric determination of hydrogen sulfide in natural waters. Limnol Oceanogr 14: 454-458.

Dahl, T.W., Anbar, A.D., Gordon, G.W., Rosing, M.T., Frei, R., and Canfield, D.E. (2010) The behavior of molybdenum and its isotopes across the chemocline and in the sediments of sulfidic Lake Cadagno, Switzerland. Geochim Cosmochim Acta 74: 144-163.

De Witt, R., and Van Gemerden, H. (1990) Growth of the phototrophic purple sulfur bacterium Thiocapsaroseopersicina under oxic/anoxic regimens in the light. FEMS Microbiol Ecol 6: 69-76.

Del Don, C., Hanselmann, K.W., Peduzzi, R., and Bachofen, R. (1994) Biomass composition and methods for the determination of metabolic reserve polymers in phototrophic sulfur bacteria. Aquat Sci 56: 1-15.

Egli, K., Wiggli, M., Klug, J., and Bachofen, R. (1998) Spatial and temporal dynamics of the cell density in a plume of 
phototrophic microorganisms in their natural environment. Documenta Ist Ital Idrobiol 63: 121-126.

Eichler, B., and Pfennig, N. (1988) A new purple sulfur bacterium from stratified freshwater lakes, Amoebobacter purpureus sp. nov. Arch Microbiol 149: 395-400.

Findlay, A.J., Bennett, A.J., Hanson, T.E., and Luther, G.W. (2015) Light-dependent sulfide oxidation in the anoxic zone of the Chesapeake Bay can be explained by small populations of phototrophic bacteria. Appl Environ Microbiol 81: 7560-7569.

Forte, E., Borisov, V.B., Falabella, M., Colaço, H.G., Tinajero-Trejo, M., Poole, R.K., et al. (2016) The terminal oxidase cytochrome bd promotes sulfide-resistant bacterial respiration and growth. Sci Rep 6: 23788.

Fossing, H., Gallardoi, V., Jorgensen, B., Hiittel, M., Nielsenl, L., Schulz, H., et al. (1995) Concentration and transport of nitrate by the mat-forming Sulphur bacterium Thioploca. Nature 374: 20.

French, C.E., Bell, J.M., and Ward, F.B. (2007) Diversity and distribution of hemerythrin-like proteins in prokaryotes. FEMS Microbiol Lett 279: 131-145.

Garcia, H.E., and Gordon, L.I. (1992) Oxygen solubility in seawater: better fitting equations. Limnol Oceanogr 37: 1307-1312.

Garcia-Robledo, E., Padilla, C.C., Aldunate, M., Stewart, F. J., Ulloa, O., Paulmier, A., et al. (2017) Cryptic oxygen cycling in anoxic marine zones. Proc Natl Acad Sci U S A 114: 8319-8324.

Gourmelon, C., Boulegue, J., and Michard, G. (1977) Oxydation partielle de l'hydrogène sulfuré en phase aqueuse. CR Acad Sci Paris 284: 269-272.

Halm, H., Musat, N., Lam, P., Langlois, R., Musat, F., Peduzzi, S., et al. (2009) Co-occurrence of denitrification and nitrogen fixation in a meromictic Lake, Lake Cadagno (Switzerland). Environ Microbiol 11: 1945-1958.

Hoang, D.T., Chernomor, O., von Haeseler, A., Minh, B. Q., and Vinh, L.S. (2017) UFBoot2: improving the ultrafast bootstrap approximation. Mol Biol Evol 35: 518-522.

Holtappels, M., Tiano, L., Kalvelage, T., Lavik, G., Revsbech, N.P., and Kuypers, M.M. (2014) Aquatic respiration rate measurements at low oxygen concentrations. PLoS One 9: e89369.

Imhoff, J.F., Süling, J., and Petri, R. (1998) Phylogenetic relationships among the Chromatiaceae, their taxonomic reclassification and description of the new genera Allochromatium, Halochromatium, Isochromatium, Marichromatium, Thiococcus, Thiohalocapsa and Thermochromatium. Int J Syst Evol Microbiol 48: 1129-1143.

Janz, G., Downey, J., Jr., Roduner, E., Wasilczyk, G., Coutts, J., and Eluard, A. (1976) Raman studies of sulfurcontaining anions in inorganic polysulfides. Sodium polysulfides. Inorg Chem 15: 1759-1763.

Jørgensen, B.B., Fossing, H., Wirsen, C.O., and Jannasch, H. W. (1991) Sulfide oxidation in the anoxic Black Sea chemocline. Deep Sea Res Part A 38: S1083-S1103.

Jørgensen, B.B., and Gallardo, V.A. (1999) Thioploca spp.: filamentous sulfur bacteria with nitrate vacuoles. FEMS Microbiol Ecol 28: 301-313.

Kallmeyer, J., Ferdelman, T.G., Weber, A., Fossing, H., and Jørgensen, B.B. (2004) A cold chromium distillation procedure for radiolabeled sulfide applied to sulfate reduction measurements. Limnol Oceanogr Methods 2: 171-180.

Kampf, C., and Pfennig, N. (1980) Capacity of Chromatiaceae for chemotrophic growth. Specific respiration rates of Thiocystis violacea and Chromatium vinosum. Arch Microbiol 127: 125-135.

Katoh, K., Misawa, K., Kuma, K.I., and Miyata, T. (2002) MAFFT: a novel method for rapid multiple sequence alignment based on fast Fourier transform. Nucleic Acids Res 30: 3059-3066.

Kirf, M.K., Dinkel, C., Schubert, C.J., and Wehrli, B. (2014) Submicromolar oxygen profiles at the oxic-anoxic boundary of temperate lakes. Aquat Geochem 20: 39-57.

Letunic, I., and Bork, P. (2016) Interactive tree of life (iTOL) v3: an online tool for the display and annotation of phylogenetic and other trees. Nucleic Acids Res 44: W242-W245.

Luther, G.W., Findlay, A.J., MacDonald, D.J., Owings, S.M., Hanson, T.E., Beinart, R.A., and Girguis, P.R. (2011) Thermodynamics and kinetics of sulfide oxidation by oxygen: a look at inorganically controlled reactions and biologically mediated processes in the environment. Front Microbiol 2: 62.

Ma, S., Noble, A., Butcher, D., Trouwborst, R.E., and Luther, G.W., III. (2006) Removal of H2S via an iron catalytic cycle and iron sulfide precipitation in the water column of dead end tributaries. Estuar Coast Shelf Sci 70: 461-472.

Manske, A.K., Glaeser, J., Kuypers, M.M., and Overmann, J. (2005) Physiology and phylogeny of green sulfur bacteria forming a monospecific phototrophic assemblage at a depth of 100 meters in the Black Sea. Appl Environ Microbiol 71: 8049-8060.

Markowitz, V.M., Chen, I.M.A., Palaniappan, K., Chu, K., Szeto, E., Grechkin, Y., et al. (2011) IMG: the integrated microbial genomes database and comparative analysis system. Nucleic Acids Res 40: D115-D122.

Marschall, E., Jogler, M., Henßge, U., and Overmann, J. (2010) Large-scale distribution and activity patterns of an extremely low-light-adapted population of green sulfur bacteria in the Black Sea. Environ Microbiol 12: 1348-1362.

Mas, J., and Van Gemerden, H. (1995) Storage products in purple and green sulfur bacteria. In Anoxygenic Photosynthetic Bacteria. Dordrecht: Springer, pp. 973-990.

Millero, F.J. (1986) The thermodynamics and kinetics of the hydrogen sulfide system in natural waters. Mar Chem 18: 121-147.

Millero, F.J., Hubinger, S., Fernandez, M., and Garnett, S. (1987) Oxidation of $\mathrm{H}_{2} \mathrm{~S}$ in seawater as a function of temperature, $\mathrm{pH}$, and ionic strength. Environ Sci Technol 21: 439-443.

Milucka, J., Kirf, M., Lu, L., Krupke, A., Lam, P., Littmann, S., et al. (2015) Methane oxidation coupled to oxygenic photosynthesis in anoxic waters. ISME J 9: 1991-2002.

Musat, N., Halm, H., Winterholler, B., Hoppe, P., Peduzzi, S., Hillion, F., et al. (2008) A single-cell view on the ecophysiology of anaerobic phototrophic bacteria. Proc Natl Acad Sci USA 105: 17861-17866.

Overmann, J., Cypionka, H., and Pfennig, N. (1992) An extremely low-light adapted phototrophic sulfur bacterium from the Black Sea. Limnol Oceanogr 37: 150-155. 
Overmann, J. (1997) Mahoney Lake: a case study of the ecological significance of phototrophic sulfur bacteria . In Advances in Microbial Ecology. Boston: Springer, pp. 251-288.

Parks, D.H., Imelfort, M., Skennerton, C.T., Hugenholtz, P., and Tyson, G.W. (2014) Assessing the quality of microbial genomes recovered from isolates, single cells, and metagenomes. Genome Res 25: 1043-1055.

Peduzzi, S., Tonolla, M., and Hahn, D. (2003) Vertical distribution of sulfate-reducing bacteria in the chemocline of Lake Cadagno, Switzerland, over an annual cycle. Aquat Microb Ecol 30: 295-302.

Peng, Y., Leung, H.C., Yiu, S.-M., and Chin, F.Y. (2012) IDBA-UD: a de novo assembler for single-cell and metagenomic sequencing data with highly uneven depth. Bioinformatics 28: 1420-1428.

Pfeffer, C., Larsen, S., Song, J., Dong, M., Besenbacher, F., Meyer, R.L., et al. (2012) Filamentous bacteria transport electrons over centimetre distances. Nature 491: 218-221.

Pfennig, N. (1975) The phototrophic bacteria and their role in the sulfur cycle. Plant Soil 43: 1-16.

Pfennig, N., Höfling, K.-H., and Kusmierz, H. (1968) Chromatium okenii (Thiorhodaceae)-Biokonvektion, aero-und phototaktisches Verhalten. Göttingen: IWF.

Polerecky, L., Adam, B., Milucka, J., Musat, N., Vagner, T., and Kuypers, M.M. (2012) Look@ NanoSIMS-a tool for the analysis of nanoSIMS data in environmental microbiology. Environ Microbiol 14: 1009-1023.

Posth, N.R., Bristow, L.A., Cox, R.P., Habicht, K.S., Danza, F., Tonolla, M., et al. (2017) Carbon isotope fractionation by anoxygenic phototrophic bacteria in euxinic Lake Cadagno. Geobiology 15: 798-816.

Prange, A., Arzberger, I., Engemann, C., Modrow, H., Schumann, O., Trüper, H.G., et al. (1999) In situ analysis of sulfur in the sulfur globules of phototrophic sulfur bacteria by X-ray absorption near edge spectroscopy. Biochim Biophys Acta (BBA) 1428: 446-454.

Schwedt, A., Kreutzmann, A.C., Polerecky, L., and SchulzVogt, H.N. (2012) Sulfur respiration in a marine chemolithoautotrophic Beggiatoa strain. Front Microbiol 2: 276.

Socrates, G. (2004) Infrared and Raman Characteristic Group Frequencies: Tables and Charts. Chichester, New York: Wiley.

Sommer, T., Danza, F., Berg, J., Sengupta, A., Constantinescu, G., Tokyay, T., et al. (2017) Bacteria-induced mixing in natural waters. Geophys Res Lett 44: 9424-9432.

Sorokin, Y. I. (1966) Role of carbon dioxide and acetate in biosynthesis by sulphate-reducing bacteria. Nature 210: 551 .

Storelli, N., Peduzzi, S., Saad, M.M., Frigaard, N.-U., Perret, X., and Tonolla, M. (2013) $\mathrm{CO}_{2}$ assimilation in the chemocline of Lake Cadagno is dominated by a few types of phototrophic purple sulfur bacteria. FEMS Microbiol Ecol 84: 421-432.

Strous, M., Kraft, B., Bisdorf, R., and Tegetmeyer, H. (2012) The binning of metagenomic contigs for microbial physiology of mixed cultures. Front Microbiol 3: 410.

Tonolla, M., Demarta, A., Peduzzi, R., and Hahn, D. (1999) In situ analysis of phototrophic sulfur bacteria in the chemocline of meromictic Lake Cadagno (Switzerland). Appl Environ Microbiol 65: 1325-1330.
Tonolla, M., Demarta, A., Peduzzi, S., Hahn, D., and Peduzzi, R. (2000) In situ analysis of sulfate-reducing bacteria related to Desulfocapsa thiozymogenes in the chemocline of meromictic Lake Cadagno (Switzerland). Appl Environ Microbiol 66: 820-824.

Tonolla, M., Peduzzi, S., Demarta, A., Peduzzi, R., and Dittmar, H.A.H.N. (2004) Phototropic sulfur and sulfatereducing bacteria in the chemocline of meromictic Lake Cadagno, Switzerland. J Limnol 63: 161-170.

Tonolla, M., Peduzzi, R., and Hahn, D. (2005) Long-term population dynamics of phototrophic sulfur bacteria in the chemocline of Lake Cadagno, Switzerland. Appl Environ Microbiol 71: 3544-3550.

Trifinopoulos, J., Nguyen, L.T., von Haeseler, A., and Minh, B.Q. (2016) W-IQ-TREE: a fast online phylogenetic tool for maximum likelihood analysis. Nucleic Acids Res 44: W232-W235.

Van Gemerden, H. (1968) On the ATP generation by Chromatium in darkness. Arch Mikrobiol 64: 118-124.

Vazquez, G., Zhang, J.Z., and Millero, F.J. (1989) Effect of metals on the rate of the oxidation of H2S in seawater. Geophys Res Lett 16: 1363-1366.

Verity, P.G., Robertson, C.Y., Tronzo, C.R., Andrews, M.G., Nelson, J.R., and Sieracki, M.E. (1992) Relationships between cell volume and the carbon and nitrogen content of marine photosynthetic nanoplankton. Limnol Oceanogr 37: 1434-1446.

Wüest, A. (1994) Interactions in lakes: biology as source of dominant physical forces. Limnologica, Jena 24: 93-104.

Zopfi, J., Ferdelman, T. G., Jørgensen, B. B., Teske, A., and Thamdrup, B. (2001) Influence of water column dynamics on sulfide oxidation and other major biogeochemical processes in the chemocline of Mariager Fjord (Denmark). Mar Chem 74: 29-51.

\section{Supporting Information}

Additional Supporting Information may be found in the online version of this article at the publisher's web-site:

Fig. S1. Profiles of the Lake Cadagno water column from 2015 taken every $\sim 4 \mathrm{~h}$ for $48 \mathrm{~h}$. Sunset was at 20:53 and sunrise at $6: 11$. Some sulfide accumulates in the chemocline in the dark and presumably reacts with $S^{0}$ to form polysulfides which is detected as sulfide by the Cline method. $\mathrm{S}^{0}$ was measured as particulate (intracellular and extracellular) sulfur on 0.7 um filters and included polysulfides which would have spontaneously oxidized during filtration. Oxygen data was not available for profiles 1 and 8.

Fig. S2. Profiles of the Lake Cadagno water column in Sept 2013 and Aug 2014 showing gradients of sulfide and oxygen, maximum turbidity in Nephelometric Turbidity Units (NTU), and temperature-conductivity ratios (T/C) in arbitrary units (a.u.). For 2014 profiles photosynthetically available radiation (PAR) and biogenic sulfate are also shown. September 2013 profiles were taken at midday (12:00), sunset (19:00) and after $1 \mathrm{~h} \mathrm{(20:00)}$ and $4 \mathrm{~h}$ 
(23:00) of darkness. August 2014 profiles were taken at the end of the day (19:00) and just before sunrise after a full period of darkness (6:00).

Fig. S3. C-assimilation rates of Chr. okenii calculated from nanoSIMS measurements of ${ }^{13} \mathrm{C} /{ }^{12} \mathrm{C}$ ratios in single-cells compared to bulk $\mathrm{C}$-assimilation rates measured in anoxic, low microoxic $\left(5 \mu \mathrm{M}\right.$ expected $\left.\mathrm{O}_{2}\right)$, medium microoxic ( $15 \mu \mathrm{M}$ expected $\left.\mathrm{O}_{2}\right)$, and light incubations performed in August 2018.

Fig. S4. (A) Light microscope image of Chr. okenii cells with intracellular sulfur inclusions. Scale bar is $10 \mu \mathrm{m}$. (B) Raman spectrum of a sulfur inclusion from a living Chr. okenii cell in an environmental sample (upper spectrum) compared to a polysulfide standard (middle spectrum) and a cyclooctasulfur standard (lower spectrum). Exposure time was $0.5 \mathrm{~s}$.

Fig. S5. The day-night dynamics of various sulfur compounds in the Lake Cadagno chemocline plotted over $48 \mathrm{~h}$ : (A) total $\mathrm{S}^{0}$ integrated over the depth of the chemocline, (B) the total sulfide flux, (C) residual sulfide accumulated in the chemocline and (D) the total (upwards and downwards) flux of biogenic sulfate. Shaded regions represent dark periods.

Fig. S6. Glycogen concentration in the chemocline is plotted in picograms per Chr. okenii cell for one day (13:00) and one night (1:30) profile from 2015.

Fig. S7. Examples of plots of sulfate concentration versus conductivity values from Lake Cadagno profiles measured in Aug 2014 at midday (16:00), sunset (19:00), and just before sunrise (6:00). A 1:1 mixing line was drawn between the end-member values from just above and below the chemocline. Points falling above this sulfateconductivity mixing line represent excess sulfate.

Fig. S8. (A) $\mathrm{O}_{2}$ concentration in $\mathrm{O}_{2}$ consumption experiments were measured every $10 \mathrm{~s}$ for $18 \mathrm{~h}$. Additions of $\mathrm{H}_{2} \mathrm{~S}$ are marked by grey arrows. $\mathrm{O}_{2}$ consumption rates 'before' and 'after' $\mathrm{H}_{2} \mathrm{~S}$ consumption are calculated along the orange marked intervals. Red intervals demark rates during $\mathrm{H}_{2} \mathrm{~S}$ consumption. (B) Summary of $\mathrm{O}_{2}$ consumption rates before, during and after the $\mathrm{H}_{2} \mathrm{~S}$ consumption. The background rates during the $\mathrm{H}_{2} \mathrm{~S}$ experiment were slightly increased when compared to the rates at the very beginning and at the very end of the incubation. (C) Mean and standard deviation of all measured $\mathrm{O}_{2}$ consumption rates before, during and after $\mathrm{H}_{2} \mathrm{~S}$ consumption.

Fig. S9. $\mathrm{O}_{2}$ concentrations in bottles incubated in parallel to ${ }^{13} \mathrm{C}$-isotope labeling incubations performed in August 2018. The low $\mathrm{O}_{2}(A)$ and medium $\mathrm{O}_{2}(B)$ incubations were injected with air to expected dissolved $\mathrm{O}_{2}$ concentrations of
$5 \mu \mathrm{M}$ and $15 \mu \mathrm{M} \mathrm{O}_{2}$, respectively, at the start of the incubations. Note the difference in scales. Consumption rates in the first hour were $8 \mu \mathrm{M} / \mathrm{h}$ which is the same as measured experimentally in August 2013 (Fig. S8).

Fig. S10. Secondary-ion images of Chr. okenii cells associated with a consortium of eukaryotic algal cells incubated with ${ }^{13} \mathrm{C}$-DIC in the light. The ${ }^{13} \mathrm{C} /{ }^{12} \mathrm{C}$ ratio (left) and ${ }^{12} \mathrm{C}^{14} \mathrm{~N}$ abundance (center) reveals ${ }^{13} \mathrm{C}$ uptake into Chr. okenii and algal cells but not the organic sheath visible in the parallel scanning electron image (right). Note that cell appear slightly less enriched than Fig. C due to the lower amount of ${ }^{13} \mathrm{C}$-bicarbonate added (7 atom \%). Cells imaged by epifluorescence microscopy (Fig. D) were displaced during removal of the coverslip and embedding material prior to nanoSIMS imaging. Cell outlines are shown in white and Chr. okenii (Chr) are indicated with arrows and algal cells $(A / g)$ are denoted with triangles.

Fig. S11. Motility characteristics of Chr. okenii in an environmental sample obtained from the chemocline during the night. (A) Trajectories of swimming Chr. okenii obtained from the image analysed video micrographs, shown here for time points corresponding to $0,4,8$ and $12 \mathrm{~s}$ of image acquisition. (B) Relative frequency distribution of swimming speeds of Chr. okenii under dark conditions. The mean swimming speed, $9.9 \pm 2.8 \mu \mathrm{m} \mathrm{s}^{-1}$, (mean \pm SD from 180 analysed cell trajectories) is indicated by the vertical black line.

Fig. S12. Contigs $(>10,000 \mathrm{kB}, \min .1 \mathrm{x} / \max .1000 \mathrm{x}$ coverage) from a combined bulk assembly of a Lake Cadagno chemocline sample and the sulfide-oxidizing enrichment culture. Size of circles represent contig size. Larger clusters and clouds signify that multiple/many contigs are located in that region. Contours of the Chromatium okenii MAG are highlighted in purple.

Fig. S13. Phylogenetic tree showing the fraction of diversity of (A) subunit 1 of the cytochrome cbb3-type hemecopper oxidases and (B) subunit 1 of the cytochrome bd-type oxidases recovered in the Lake Cadagno metagenome, with NorB as the outgroup. Only those sequences affiliated with bacteria known to participate in oxidative sulfur cycling are shown. Chr. okenii sequences from the bulk metagenome and MAG have been de-replicated and both gene IDs are shown.

Table S1. Sequencing and assembly statistics for the metagenomics datasets recovered from the Lake Cadagno chemocline and a phototrophic, sulfide-oxidizing enrichment culture.

Movie S1. Video of Chr. okenii swimming in the dark. 